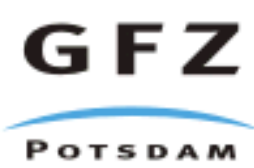

Originally published as:

de Wit, M. (2007): The Kalahari Epeirogeny and climate change: differentiating cause and effect from core to space. - South African Journal of Geology, 110, 2-3, 367-392,

DOI: 10.2113/gssajg.110.2-3.367 


\title{
The Kalahari Epeirogeny and climate change: differentiating cause and effect from core to space
}

\author{
Maarten de Wit \\ GFZ - GeoForschungsZentrum Potsdam,Telegraphenberg, 14473 Potsdam, Germany, \\ and AEON - Africa Earth Observatory Network, University of Cape Town, Rondebosch, 7700, South Africa \\ e-mail: maarten.dewit@uct.ac.za
}

(C) 2007 September Geological Society of South Africa

\begin{abstract}
Southern Africa's high Kalahari plateau and its flanking mountain ranges formed over an extended period of $\sim 200$ million years through vertical tectonic processes different from those at convergent plate boundaries. We refer to this as the Kalahari epeirogeny. Episodic uplift and erosion during the Kalahari epeirogeny is inferred from thermo-chronology and from stratigraphy of sediment accumulated around its continental margin. A total thickness of 2 to $7 \mathrm{~km}$ of rock (of which basalt was a major component) was eroded from the subcontinent's surface during two punctuated episodes of exhumation, in the early-Cretaceous and in the mid-Cretaceous. Major exhumation was over by the end of the Cretaceous, and the rate of erosion decreased by more than an order of magnitude to remove less than $1 \mathrm{~km}$ thickness of rock during the Cenozoic. Cosmogenic dating shows that erosion rates today are almost an order of magnitude less still.

The cause for the Kalahari epeirogeny remains elusive, but three striking observations stand out: (i) major exhumation occurred during the late Mesozoic break-up of Gondwana; (ii) large scale basaltic magmatism closely match two accelerated episodes of exhumation: first along the west coast ( $132 \mathrm{Ma}$, Etendeka large igneous province [LIP], associated with vast amounts of underplating along this entire passive margin), and the second flanking the sheared south coast margin ( $\sim 90$ Ma, Agulhas oceanic LIP). Yet exhumation that might have accompanied the vast Karoo LIP ( 180 Ma) is not readily detected; (iii) the two main regional episodes of accelerated exhumation and coastal sediment accumulation are near synchronous with two regional 'spikes' of kimberlite intrusions: $>450$ kimberlites at $\sim 90 \mathrm{Ma}$, and >200 kimberlites at $\sim 120 \mathrm{Ma}$.

Southern Africa is underlain by an anomalous warm region in the lowermost $\sim 1500 \mathrm{~km}$ of the mantle that is linked to core to mantle heat loss. This warm region was inherited from a large Cretaceous thermo-chemical anomaly in the mantle created during long-lived subduction beneath Gondwana. Associated Mesozoic kimberlite genesis and basaltic magmatism may have been sufficient to cause volatile/heat-induced density changes in the lithospheric mantle of southern Africa to sustain the Kalahari plateau. In addition, such changes may have been induced by tectonic uplift and decompressional melting resulting from far-field collision processes between Africa and Europe, and/or final continental lithosphere decoupling between the Falkland plateau and southern Africa. $\mathrm{CO}_{2}$ released into the ocean-atmosphere system during the Kalahari epeirogeny contributed to the global mid-Cretaceous hot-house conditions. However, because the $\mathrm{CO}_{2}$-consumption rate associated with basalt weathering is about eight times that of granite, atmospheric $\mathrm{CO}_{2}$ was also efficiently sequestrated during the rapid erosion of Karoo basalt. Thus, the Kalahari epeirogeny also may have catalysed the onset of long-term global Cenozoic cooling.
\end{abstract}

\section{Introduction}

Epeirogeny, defined more than 100 years ago by Gilbert, refers to vertical warping of the lithosphere, a feature of the Earth recognised as far back as Lyell and Darwin (see Menard, 1973 for review and references). Pre-plate tectonic discourse about epeirogeny, including formation of regional plateaus, created well-known geodynamic schools that related Earth's geological processes to vertical forces on the lithosphere (e.g. Umbgrove, 1947; Stille, 1948; Beloussow, 1962; van Bemmelen, 1966; and Ramberg, 1967). Epeirogeny occurs, however, on a plate tectonic Earth, and today more than 15 different mechanisms have been proposed to explain this vertical lithosphere motion at the surface of the solid Earth that is dominated by tangential tectonic forces (e.g. Isacks et al., 1973; McKenzie, 1984; Beaumont et al., 2001). There is widespread agreement that thermal processes are important in virtually every case of regional plateau uplift, and also that detailed information on upper mantle structure and composition is vital for resolving these different models of vertical lithosphere motions (e.g. Isacks et al., 1973; McGetchin and Merrill, 1979; McGetchin et al., 1980; Fuchs et al., 1983; Neugebauer et al., 1983; Molnar et al., 1993; Beaumont et al., 2001).

Africa is unique in that the southeastern half of this continent has been affected by plateau uplift during a time when it was far removed from convergent plate boundaries such as subduction and collision zones (e.g. Burke 1996; Doucouré and de Wit, 2003a; Figure 1). Thus, vertical forces contributing to epeirogeny can be more easily isolated in Africa than in other high continental regions where horizontal forces are dominant, such as the Colorado Plateau (e.g. Thompson and Zoback, 1979), the Andean Altiplano (e.g. Oncken et al., 2006), the Tibetan Plateau (e.g. Beaumont et al., 2001), and more localized uplifts such as the Rhenish Massif (e.g. Illies et al., 1979).

Continental plateaus are recognized as important elements in regional and global dynamic studies 


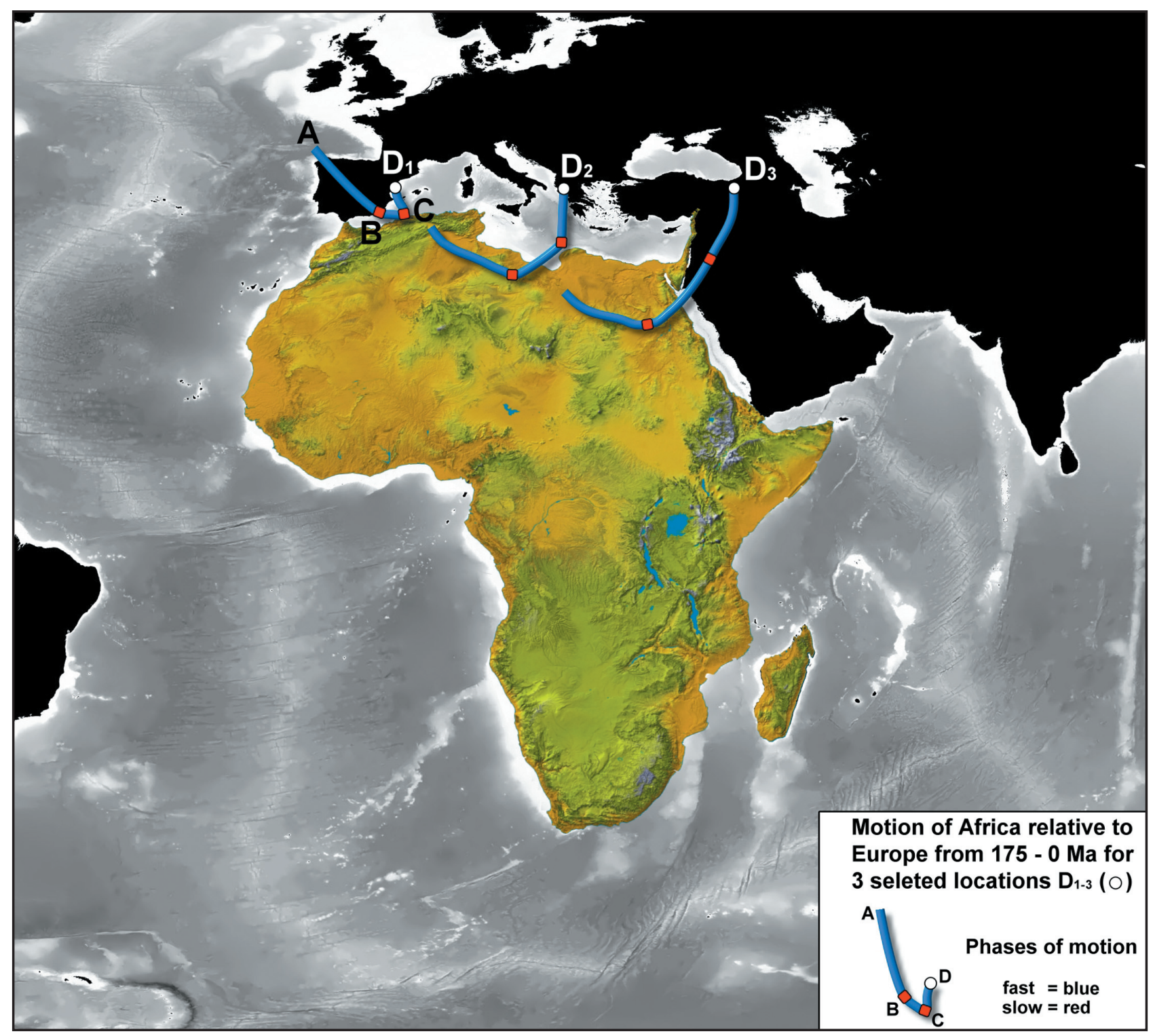

Figure 1. General topography of the African Plate, which emphases that the African continent is dominated by two broad $\left(>1000 \mathrm{~km}^{2}\right)$ elevated regions in the southeast (greens; 500 to $3000 \mathrm{~m}$; average elevation $=1015 \mathrm{~m}$, with local peaks at $>5 \mathrm{~km}$ ): (i) the volcanically active northeast African Highlands, and (ii) the quiescent southern Kalahari Africa Plateau (range 900-1200 m, with local non-volcanic peaks just less than $3500 \mathrm{~m}$ - Thabana Ntlenyana - $3482 \mathrm{~m}$ ). The more subdued low-lying terrain of central-, west- and north-Africa (yellows; 300 to $1500 \mathrm{~m}$; average elevation $=450 \mathrm{~m}$ ) is interspersed regionally with local high volcanic centres such as Tibesti at $>3 \mathrm{~km}$ (for discussion of this bimodal African topography and its origin, see Doucouré and de Wit, 2003a). Note that the continent is surrounded mostly by midocean ridge plate boundaries; only the sector from the Atlas Mountains to the eastern Mediterranean is part of the (complex) convergent plate boundary between Africa and Eurasia, driven by oceanic lithopshere slab retreat towards Africa. Three parallel paths of past motions of Africa relative to Eurasia are shown from three present day locations (white circles $\mathrm{D}_{1-3}$ ) backwards to the start of this motion at $175 \mathrm{Ma}$ (points A). Motions between the two continents are fast for the periods represented by the blue segments, and reach near stand-still for $\sim 20$ to $\sim 15 \mathrm{Ma}$ at the red squares (age span at $\mathrm{B}=\sim 140$ to $\sim 125 \mathrm{Ma}$; at $\mathrm{C}=\sim 75$ to $\sim 55 \mathrm{Ma}$; adapted from Smith (2006).

because of their effects on, and response to, the oceanatmosphere system, forcing climate change, erosion and run-off, and tectonic uplift (e.g. Molnar and England, 1990; Edmond, 1992; Raymo and Ruddiman, 1992; Veizer et al., 1999; Dupré et al., 2003; Fluteau 2003; Lamb and Davis, 2003; Alonso et al., 2006; Bayon et al., 2006). To track paleo-epeirogeny and related earth systems on a global scale, such as during Gondwana break-up and continental drift, models must also incorporate the changing paleo-geography of its shifting continental fragments such as Africa. The time-integrated paleo-positions of Gondwana continents are now known to within acceptable limits for high resolution numerical and graphical modeling to facilitate paleogeographical reconstructions (Scotese, 2001; Reeves and de Wit, 2000; Rosenbaum et al., 2002; Jokat et al., 2003; Collins, 2003; Stampfli and Borel, 2004; König, 2006; Smith 2006).

Burke and Wilson (1972) and Burke (1976; 1996) suggested that because the horizontal motion of the 
African continent came to rest with respect to the mantle at $\sim 30 \mathrm{Ma}$, the entire continent responded to this stasis by epeirogeny through thermal feedback with its underlying mantle. They concluded from this that large scale epeirogeny is likely to occur when continents come to such a standstill, and that this would be manifested by regional alkaline-dominated igneous activity. This is compatible with a manifold of geoscientific observations across the highlands of East Africa where the intense Cenozoic volcanism peaked between $\sim 20$ and $\sim 40 \mathrm{Ma}$ (e.g. Bond, 1979, Crough 1979 , Smith, 1994; Ebinger and Sleep, 1998; Nyblade et al., 2000 a; b; Yirgu et al., 2006 and references therein), but not so for high southern Africa, which is dominated by Mesozoic alkaline volcanism and was already a high region at that time (Doucouré and de Wit, 2003a).

Relative motions between the Africa and Eurasia plates also changed episodically during the Mesozoic. Substantial slowing in the rate of convergent motion between the two continents occurred during the end Mesozoic, at times leading to a 'gridlock' between them (e.g. Smith, 1971; 2006; Figure 1). It is possible therefore that this too affected the thermal balance between the African lithosphere and its underlying mantle. Evidence for such far-field effects might be preserved in southern Africa where repeated regional uplift and diffuse alkaline magmatism (in the form of more than a thousand kimberlites and related mantle-derived rock types, many of which have been dated) occurred in tandem during punctuated episodes: the two biggest 'jerks' in cooling and uplift/exhumation calculated from fission track data across the Kalahari plateau and from the accumulation-rates of the eroded products around its margins, are at $\sim 120$ and $\sim 90 \mathrm{Ma}$, both episodes that coincide with two intense, short-lived episodes of kimberlite intrusions. (e.g. Jelsma et al., 2004; Tinker 2005; Tinker et al., 2007, in review).

Other proposed geodynamic models compatible with the present high topography of Africa, include:

(i) plume head impingement of the lithosphere under southern Ethiopia (Ebinger and Sleep, 1998), and/or under the eastern margins of the Tanzanian craton (Nyblade et al., 2000b);

(ii) dynamic topography due to vertical stresses at the base of the southern African lithosphere generated by flow in the lower mantle, or positive buoyancy in the mid-lower mantle beneath southern Africa (Lithgow-Bertelloni and Silver, 1998; Ritsema et al., 1999; Gurnis et al., 2000).

Seismic tomography studies show that a substantial region of lower mantle beneath southern Africa is presently anomalously hot and possibly also chemically different from the surrounding and overlying mantle (e.g. Montelli et al., 2006, and references therein). If this deep mantle thermal perturbation beneath southern Africa is responsible for its present-day high topography, this would implicate its existence also in the Mesozoic, because the timing of major uplift and associated alkaline volcanicity of southern Africa date primarily to this time. However, temperature gradients in the mantle transition zone and upper mantle beneath southern Africa and northeastern Africa today are fundamentally different: it is 'hot' directly beneath east Africa, and 'cold' directly beneath southern Africa (e.g. Crough, 1979; Doucouré and de Wit 2003a; Montelli et al., 2006; Shen and Blum, 2003; Benoit et al., 2006). These differences may, therefore, represent distinct phases of deep mantle thermal dynamics, perhaps triggered by temporal variations of heat flux across the core-mantle boundary, in which case answers to epeirogeny might be recorded in past variations of Earth's outer core convection and hence its paleo-magnetic field (c.f. Nicolayson, 1985a; b; Loper and McCartney, 1986; Larson 1991; Courtillot et al., 1978; 2007; Dormy and Mandea 2005).

Such a fundamental causal relationship that may exist between epeirogeny and core-mantle processes should be preserved in the stratigraphic record (c.f. White and Lovell, 1997; Courtillot et al., 2007), and can now be numerically modeled and tested (Bunge et al., 1998; Bunge et al., 2002; Conrad and Gurnis, 2003). Southern Africa is the world's best field laboratory where this can be accomplished (e.g. de Wit and Horsfield, 2006). We examine some of these issues below, in the framework of this natural laboratory and in context of the African plate as a whole.

\section{High topography of Africa}

Africa is surrounded mostly (>90\%) by extensional plate margins in the form of spreading ridges. Yet Africa is host to some of the world's greatest elevated regions. Africa's topography is therefore unique in a global perspective. Whereas elevated topography of most continents can be related to processes across compressional plate tectonic margins (e.g. Andes, Cordilleras, Himalayas, Tibet), this is not so for Africa (Figure 1).

Africa's first-order, long wavelength, topography is distinctly bimodal (Figure 1). Southern Africa and eastern Africa are rugged and of elevations generally $>1000 \mathrm{~m}$; central- and west-Africa are relatively smooth at $<500 \mathrm{~m}$. Poor correlations between free-air gravity and surface topography at long wavelengths show that the broad African uplifts are not simple crustal features, and that the bimodal topography must be linked to sources as deep as the sublithospheric mantle. Positively correlated features between gravity and geographic features in Africa (e.g. the basins and swells of Holmes, 1965) are limited to second order epeirogenic effects and confined to the lithosphere (Doucouré and de Wit, 2003a, and references therein).

There is considerable controversy about the age and origin of these topographic features and the bimodal topography of Africa in particular. Some workers believe most of these to be Cenozoic in age (du Toit, 1933; King, 1951; 1967; Burke, 1996; and see Partridge and Maud, 1987; 2000). Others believe that a significant number of the features date to the Mesozoic (Sahagian 1988; 


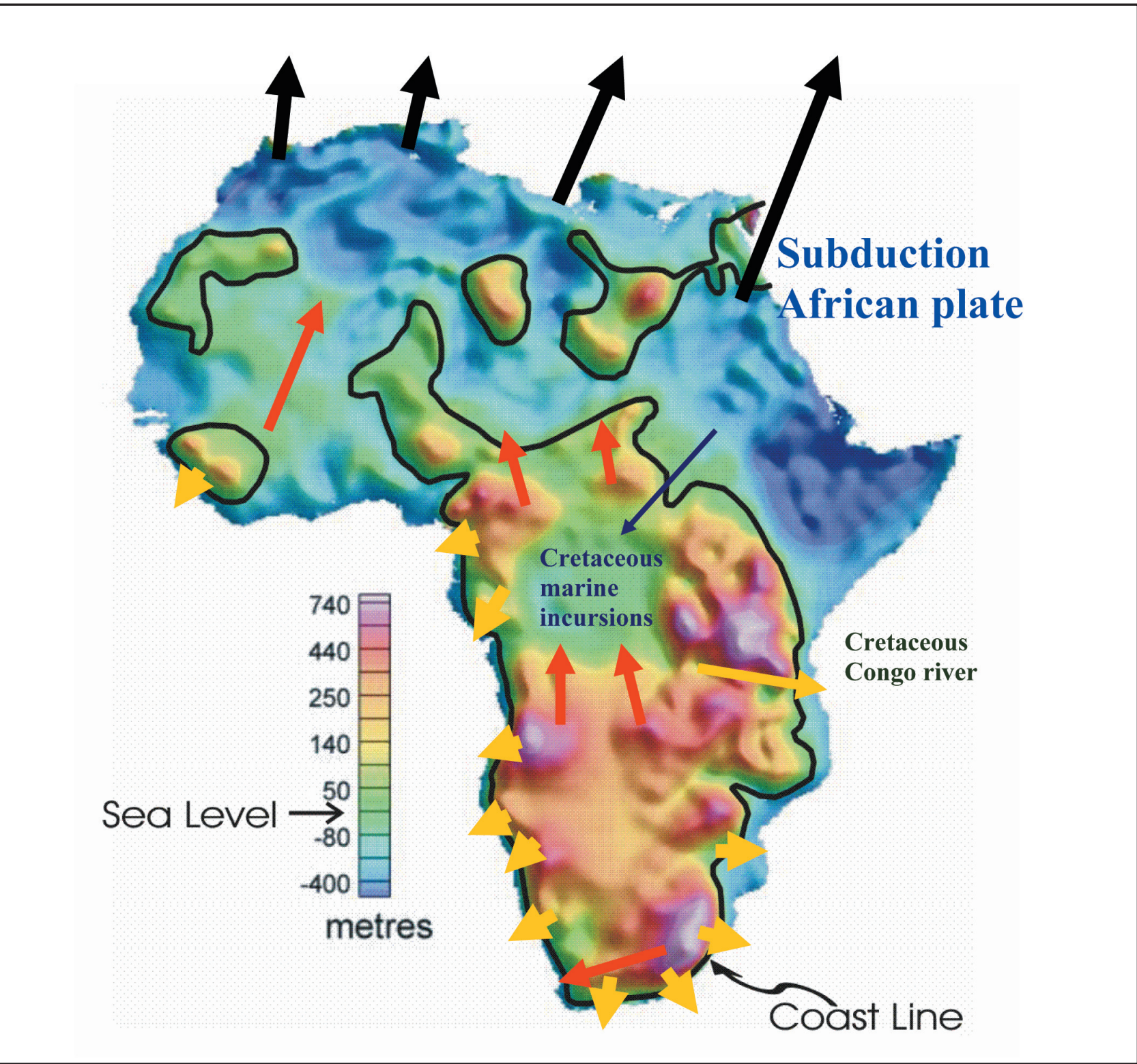

Figure 2. Mesozoic topographic model of Africa normalised to the high sea level of the ice-free Cretaceous greenhouse world (e.g. Jenkyns et al., 2004). At this time, Africa has lower total aerial relief relative to today, yet still appears bimodal, compatible with Jurassic-Paleocene geology that indicates that northern and central Africa were mostly a continent of low relief $(\leq 600 \mathrm{~m})$, with large tracks below sea level. Southern Africa was rugged and well above sea level, with relief ranging from sea level (along the Indian Ocean coast stretching from Mozambique to Natal, South Africa) to $\geq 750 \mathrm{~m}$. The general paleo-topography shows that the Paleo-Congo River probably drained into the Proto-Indian Ocean with occasional incursions of this ocean into the African interior from the northeast (Stankiewicz and de Wit, 2006). Red Arrows= direction of dispersal of Cretaceous alluvial diamond deposits (e.g. Central African Republic, Censier, 1996; northern Kalahari Plateau-edge into the southern Congo basin, de Beers, unpublished data; and the Karoo River, a paleo-Orange River, de Wit, 1993). Yellow Arrows= Direction of Cretaceous coastal sediment dispersal. Black Arrows= general direction of relative motion Africa-Europe from $140 \mathrm{Ma}$ to present, during the subduction and roll back beneath Africa of extensive tracks of Tethyan oceanic lithosphere (see figure 1 and text for further explanation; modified from Doucouré and de Wit 2003a)

Fairhead and Binks, 1991; Guiraud et al., 1992; de Wit, 1993; de Wit et al., 2000; Brown et al., 1995; 2000; 2002; Foster and Gleadow, 1996; Partridge and Maud, 1987; Partridge 1998; Moore, 1999; Tinker, 2005; Tinker et al., 2007 in review).

Doucouré and de Wit (2003a) quantified an early Mesozoic paleo-topography of Africa by removing topographic effects of significant surface features known to be Cretaceous or younger in age. They found that the bimodal topography of Africa is a feature inherited from the Mesozoic, and possibly even earlier times, and that southern and south-central Africa was a Mesozoic plateau similar in extent as the present Kalahari highlands and its flanking mountain ranges (Figure 2). This region has experienced a sustained history of vertical motion, therefore, far away from geodynamic processes at convergent plate boundaries. Here, we refer to this long period of vertical movements of this region 


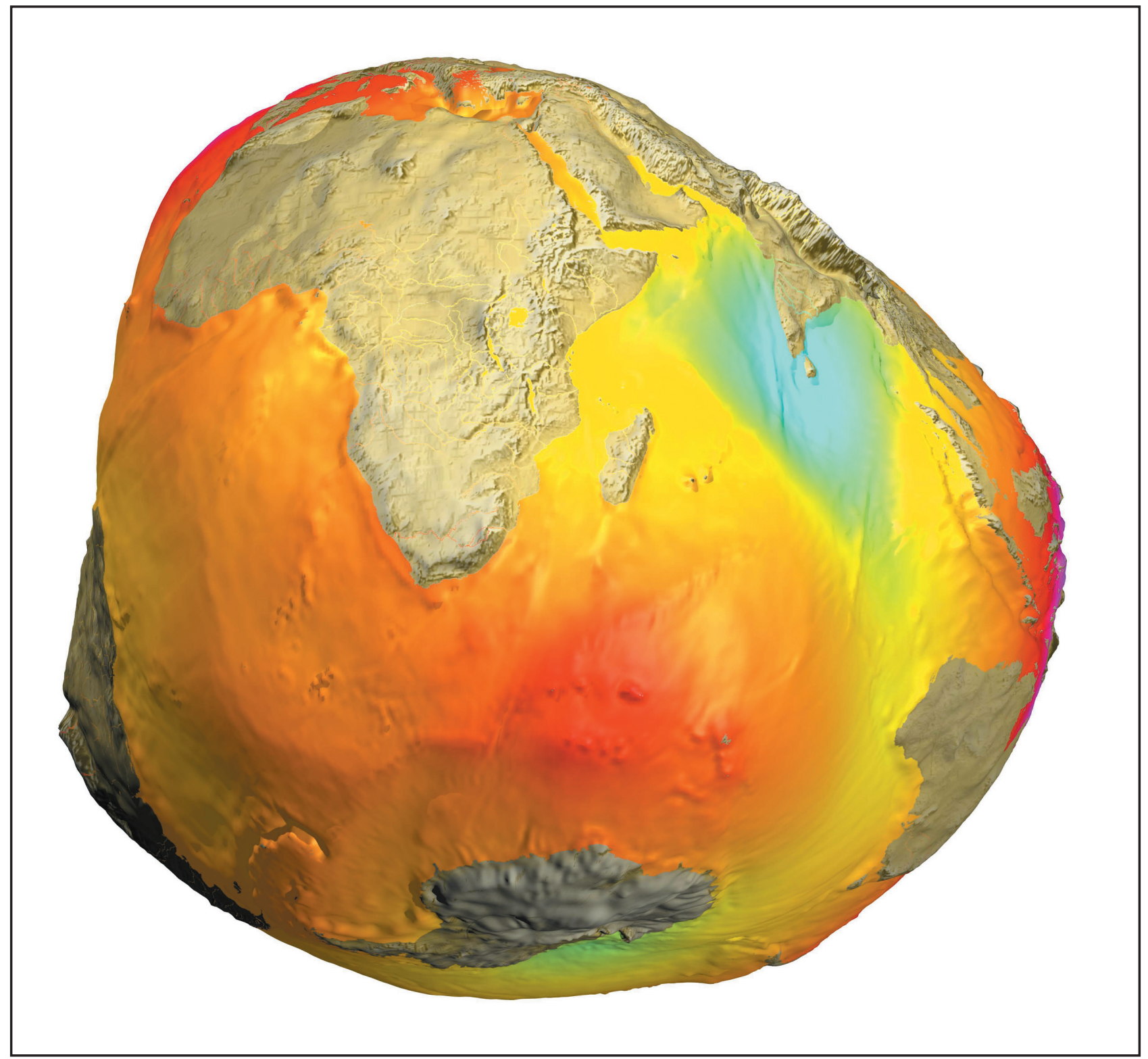

Figure 3. Geoid- Earth shape; blues= lows; reds=highs. This perspective emphasises the geoid's high across southern Africa and surrounding oceans. There is a close spatial correspondence between this geoid high and the underlying low velocity zone that extends $\sim 1500 \mathrm{~km}$ above the core mantle boundary, as determined from global seismic tomography. This spatial correlation supports models that implicate that the relatively high topography of the southern African plate, and the Kalahari Shield in particular, are dynamic features related to the lower mantle convection processes (e.g. Lithgrow-Bertelloni and Silver, 1998; see text for further explanation). Because the topography of the Kalahari Plateau has been high since the Mesozoic, it is speculated that the low velocity zone, and by inference the geoid high over this region, has been preserved for at least $200 \mathrm{Ma}$, and was created before Gondwana dispersal times (e.g. Le Pichon and Huchon, 1985; see text for further explanation). Figure courtesy of A. Helm, GFZ-Potsdam. Geoid model EIGEN-CG01C, GFZ-Potsdam is a high resolution global gravity field model combining CHAMP and GRACE satellite missions and surface data. The overall accuracy of the model is estimated to be $20 \mathrm{~cm}$ and $5 \mathrm{mgal}$; accuracy over the oceans is greater than over the continents. Gravitational potential in geoid heights: red-yellow $=+20$ to +80 meter; blues $=-60$ to +100 meter. For more detailed information: http://www.gfz-potsdam.de/champ/ and http://icgem.gfz-potsdam.de/ICGEM/ICGEM.html.

For a rotating animation of this geoid, see: http://www.gfz-potsdam.de/pb1/pg3/grim/anim-pot-2002/animated-potato-e.html

as the Kalahari epeirogeny, and examine its possible causes.

\section{Deep mantle structure beneath ancient southern Africa.}

The present high topography of southern Africa has been attributed to dynamic uplift linked to upwelling of anomalously hot material in the lower mantle (e.g. Nyblade and Robinson, 1994; Grand et al., 1997; Lithgow-Bertelloni and Silver, 1998; Grand 2002; Conrad and Gurnis, 2003). There is considerable debate about the effectiveness of such upwelling in sustaining a high surface topography. How fast and long can upper mantle plumes derived from the lower mantle support a 
high surface topography? Nyblade and Sleep (2003) have shown numerically that Mesozoic mantle plume heads would not have been effective in sustaining lasting uplift throughout the Cenozoic, unless associeted plume tails lingered beneath southern Africa for 25 to $30 \mathrm{Ma}$. By contrast other numerical simulation shows that onset of lower mantle upwelling would be instantaneously transmitted to the lithosphere, and could thus account for contemporaneous epeirogeny (e.g. Bunge et al., 2002; and personal communication. 2007). The distinct geoid high over southern Africa and its surrounding oceans (Figure 3) is compatible with such dynamic mantle support of the lithosphere.

In all recent global tomographic studies, Earth's lower mantle is characterized by two anomalously low seismic-velocity zones of great regional extent, also referred to as superplumes. One of these is centered beneath southern Africa and its surrounding oceans. (e.g. Nyblade and Robinson, 1994; Grand et al., 1997; Ritsema et al.,1999; Nyblade et al., 2000a; b; van der Hilst and Kárason, 1999; Grand 2002; Zhao 2004; Montelli at al., 2004; and see Montelli et al., 2006, for overview). From just above the core mantle boundary (CMB) up to the middle mantle, the African superplume is seismically most pronounced directly beneath southern Africa. From there it extends north to central Africa and westward across its surrounding ocean almost as far as the mid-oceanic ridge of the South Atlantic. In a southeast direction, the low-velocity anomaly extends into the southern Indian Ocean as far as Kerguelen (see, for example, figure 10 in Montelli et al., 2006).

Below southern Africa, the low velocity region has a height of $\sim 1200$ to $1700 \mathrm{~km}$, (i.e. $\sim 1000$ to $1500 \mathrm{~km}$ beneath the Southern African lithosphere), disappearing well below the upper mantle transition zone (410 to $660 \mathrm{~km}$ ). A seismic study using receiver function analyses has identified a possible reflector at about 1500 $\mathrm{km}$ that may coincide with this upper boundary of the superplume (Blum and Shen, 2004). At about this level, this deep low velocity zone beneath southern Africa links up horizontally with the lower bounds of a shallower low velocity region of the upper mantle directly beneath the East African Rift and the Afar (Montelli et al., 2006; see their Figure 13). This linkage is also imaged clearly on other tomographic models of the upper mantle of that region (e.g. Nyblade et al., 2000a; b; and Benoit et al., 2006, and references therein).

The low velocity region below East Africa and the Afar indicates upper mantle temperatures elevated by up to $\sim 300^{\circ} \mathrm{K}$, consistent with the fact that beneath East Africa the $660 \mathrm{~km}$ discontinuity is shallower, and the $410 \mathrm{~km}$ discontinuity is depressed by 30 to $40 \mathrm{~km}$ (Nyblade et al.,2000a; b; Nyblade and Langston, 2002; Benoit et al., 2006). This implies that this low velocity region is at least in part related to excess heat, possibly transferred from the lower mantle region beneath southern Africa (Ritsema et al., 1999; Nyblade et al 2000b; Doucouré and de Wit, 2003a; Benoit et al., 2006;
Montelli et al., 2006). In turn, this supports interpretations that the low velocity region below southern Africa is principally a thermal heterogeneity that represents differential heat loss from the core (Bunge et al., 1998; Davaile, 1999). If correct, it follows that presently this excess heat is convected laterally from the low-mid mantle beneath southern Africa to the upper mantle below East Africa.

By contrast, the upper mantle beneath southern Africa (and directly beneath the superplume) is not anomalously warm. Seismic studies of converted waves (receiver functions) show that the transition zone is well-defined below southern Africa and its bounding 410- and $660-\mathrm{km}$ discontinuities are both found at their expected depths, so that the temperature in the upper mantle below the southern African lithosphere is close to, or even slightly lower than the global average mantle temperature at that depth (Stankiewicz et al., 2002; Blum and Shen, 2004; Chevrot and Zhao, 2007). In turn, this suggests that the mantle superplume is not presently responsible for the current high topography of southern Africa through heat transfer, consistent with the absence of present-day igneous activity at surface here.

Detection of mid-mantle discontinuities between 1000 to $500 \mathrm{~km}$, using seismic and gravity modeling (Ishii and Tromp, 1999; Le Stunff et al., 1995; Blum and Shen 2004), indicates that the African superplume may also be defined by chemical layering. Thus, the upper surface of the low velocity zone is likely the thermochemical neutral boundary of a large superplume that supports the elevated topography of Africa (c.f. Davaile 1999; Courtillot et al., 2003). It has been speculated, on the basis of off-shore stratigraphy (Dale and McMillan, 1999; Partridge and Maud, 2000), that this upper surface of the superplume beneath southern Africa has subsided, on average, in the Cenozoic whilst concomitantly it gradually surfaced beneath East Africa (Doucouré and de Wit 2003a). Regional variations in alkaline igneous activity suggest that the horizontal deflection of heat in the mid-mantle is relatively recent (<40 Ma). Earlier, between $\sim 60$ and $200 \mathrm{Ma}$ the superplume may have reached higher levels below southern Africa during periods of extensive and widespread alkaline volcanism across southern Africa, (Doucouré and de Wit, 2003a; Jelsma et al., 2004). This is consistent with fission track dating and with accelerated sediment accumulation in the Cretaceous, followed by a distinct unconformity above which relatively low volumes of Cenozoic sediment are preserved around the margins of southern Africa (Dingle et al., 1983; Brown et al., 1995; Tinker, 2005; Tinker et al., 2007 under review; Paton et al., 2007).

\section{Timing and rates of uplift in southern Africa}

Most of the vertical motions of Africa are indeterminate using sea level changes (Bond, 1979). Resolving details of its epeirogeny, therefore, requires thermochronological analyses based on for example, Fission Track Analyses (FTA) and U/Th/He dating of selected 
minerals, and other geomorphic dating techniques of erosion surfaces. Furthermore, good quantitative chronological control to evaluate major uplift/ exhumation/denudation events can be tested using stratigraphy offshore: to a first order basis what is lost from the continent should be gained around its margins.

Until recently there has been little consensus about the precise timing, duration and magnitude of Africa's uplift, denudation and exhunation, because estimates are based mainly on geomorphological studies that hinge on the identification of remnant erosional surfaces to which conflicting ages have been assigned. This practice has been severely criticized Summerfield (1996) and Brown et al. (2000).

A number of studies using onshore FTA (Gallaher and Brown, 1999; Brown et al., 2000; 2002; Raab et al., 2002; Tinker 2006; Tinker et al., 2007 in review; Kounov et al., 2007 in review), and off-shore seismic-, litho- and bio-stratigaphy (Brown et al., 1995; McMillan et al., 1997; McMillan, 2003; Paton et al., 2007) have established a robust and consistent set of first order conclusions about the general age of uplift and erosion across southern Africa. In addition, FTA analyses on outcrop and borehole samples have been integrated with onshore denudation to off-shore sediment accumulation over the last 150 million years, using the wealth of seismic and borehole data along the south coast of Africa, to test in detail the temporal balance between the amount of onshore erosion across the southern Cape against the volume of sediment that has accumulated along this southern margin since the break-up of Gondwana (Brown et al. 2000; Tinker, 2005; Tinker et al., 2007 in review).

Tinker (2005) used apatite FTA (AFTA) on samples from deep boreholes far enough inland for cooling to be unrelated to the thermal processes associated with continental rifting and shoulder uplift during Gondwana break-up (e.g. >150 km from the rift margin), to track their burial and exhumation history (Tinker 2005; Tinker et al., 2007 in review). Additionally, complementary AFTA along a transect from the Kaapvaal Craton to the coast in the south on samples of Paleozoic to early Mesozoic age, yield mid-upper Cretaceous AFT dates but no Cenozoic ones. This suggests that rapid exhumation was over by $\sim 65 \mathrm{Ma}$. A significant decrease in the volume of accumulated Cenozoic sediments around southern Africa also signals the onset of a sharp concomitant deceleration in exhumation across the subcontinent, and that denudation thereafter was less than $1 \mathrm{~km}$.

Thermal modeling of AFT data shows that the region flanking the south coast and the region along the west coast of southern Africa were stripped by $\sim 4$ to $6.5 \mathrm{~km}$ of overburden in the Cretaceous, almost half of which were basalts of the Karoo volcanics. Farther inland, beyond the escarpment, this was on the order of $\sim 2 \mathrm{~km}$, decreasing to $\sim 1.4 \mathrm{~km}$ or less near the centrel of the Kaapvaal Craton (Hawthorne, 1975), and less than $850 \mathrm{~m}$ since $\sim 85 \mathrm{Ma}$ around Kimberley (Hanson, et.al.
2006), much of which was also basalt that covered the present regional exposed Karoo dolerite sill complexes (e.g. Chevallier and Woodward, 1999; Moore and Blenkinsop, 2006; Jourdan, et al., 2007). Ubiquitous erosion surfaces of the Cape Mountains, now exposed up to $2 \mathrm{~km}$ above sea level, were also buried by over $2 \mathrm{~km}$ of rock. The famous late Paleozoic Cape Fold Belt is in reality a mountain region exhumed and resculptured in the Cretaceous (Tinker, 2005; Tinker et al., 2007 in review).

Although the calculated onshore eroded sediment volume does not match that accumulated offshore (the calculated offshore sediment volumes are minimum values, in part because much of the basalts were chemically weathered), the timing of changes in onshore denudation and denudation rates matches rather well the timing of changes in offshore sediment accumulation and accumulation rates. Specifically along the south coast, high denudation in the early Cretaceous $(\sim 140$ to $\sim 120 \mathrm{Ma})$ is matched by high offshore accumulation ( $\sim 136$ to $\sim 120 \mathrm{Ma})$. A drop in denudation and denudation rate between $\sim 120$ and $\sim 100 \mathrm{Ma}$ is coupled to a drop in accumulation and accumulation rate between $\sim 120$ and $\sim 95 \mathrm{Ma}$, followed by a second pronounced increase in denudation and denudation rates in the mid Cretaceous ( 100 to $\sim 80 \mathrm{Ma}$ ), the timing of which is closely matched by increased accumulation and accumulation rate, at $\sim 95$ to $\sim 70 \mathrm{Ma}$. A profound unconformity at $\sim 67 \mathrm{Ma}$, covered by a relatively thin Cenozoic sediment sequence around off-shore southern Africa (Dingle et al., 1983; Brown et al., 1995; McMillan 2003; Tinker 2005; Paton et al., 2007), and the lack of Cenozoic FTA dates attest to the coupled decline between off-shore sediment accumulation rates and onshore exhumation.

Along the west coast of southern Africa a slightly different onshore exhumation story has emerged (Kounov et al., 2006; 2007, this volume). Precambrian to early Jurassic rocks (Karoo dolerite) all yield AFTA dates ranging between $\sim 180$ to $\sim 85 \mathrm{Ma}$, with the older ages characteristic for the continental interior above the escarpment, where the topographically highest sample (dolerites) yield AFTA dates close to its emplacement age $(\sim 183 \mathrm{Ma})$, implying that less than $\sim 2 \mathrm{~km}$ overburden has been removed since its intrusion. Samples from the coastal plain have significantly younger ages ( 115 to $100 \mathrm{Ma}$ ), indicating a large amount of denudation in the areas along the coastal plains, seaward of the escarpment.

Thermal modeling of the samples from this region also resolves two distinct cooling events. The first, between $\sim 160$ and $\sim 138 \mathrm{Ma}$, is restricted to the west coast. This likely reflects tectonic shoulder uplift and denudation related to early Gondwana rifting bordering the South Atlantic, particularly in South America where it was accompanied by widespread crustal melting between $\sim 150$ to $190 \mathrm{Ma}$ (e.g. Figure 4; Stern and de Wit, 2004, and references therein) and which culminated in the emplacement of the Etendeka continental flood 


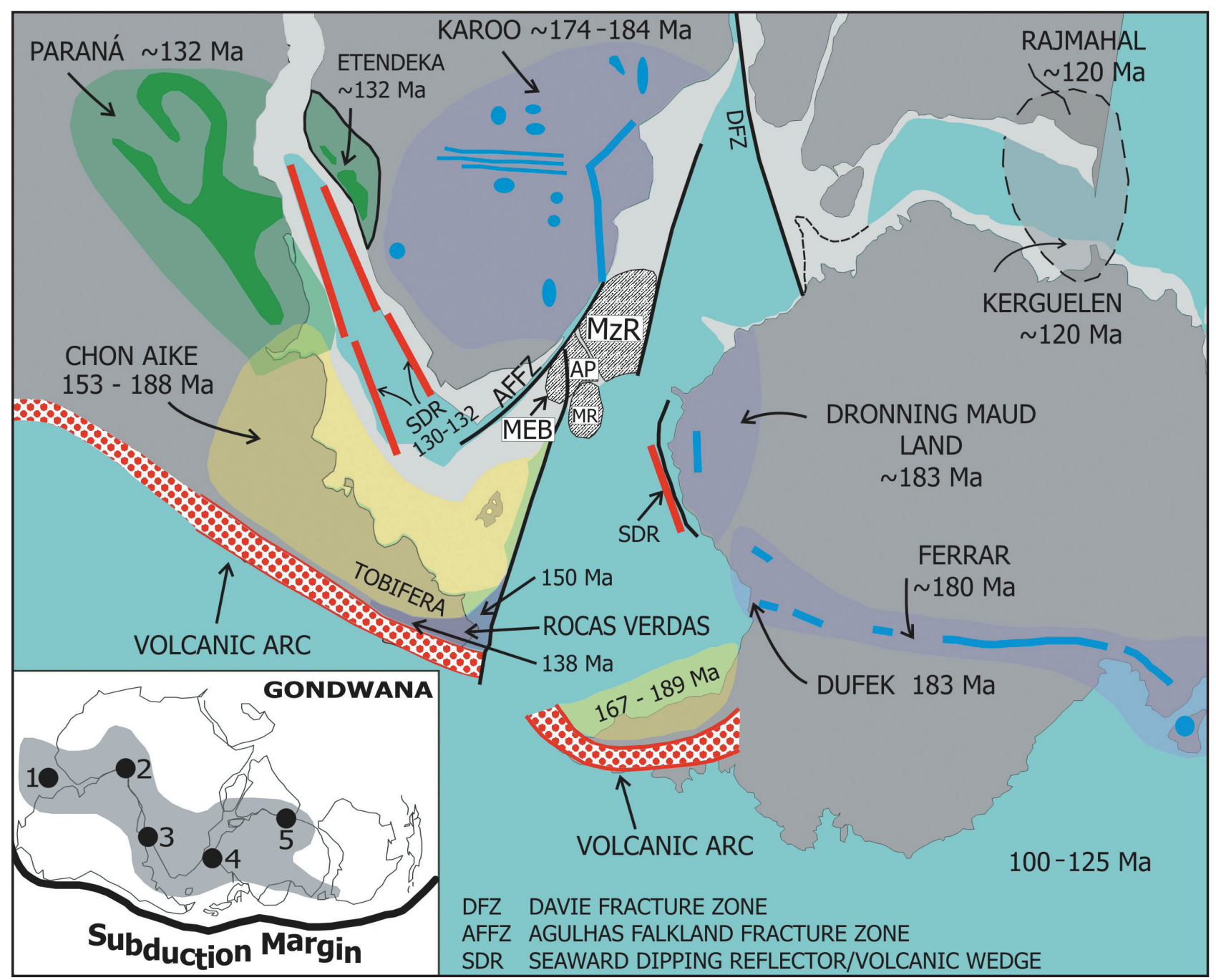

Figure 4. Selected igneous and tectonic elements associated with the break-up of Gondwana Note that the opening of the South Atlantic is preceded by the large bimodal Chon Aike LIP of southern South America, and that the final opening of a backarc basin along the paleoPacific margin of Gondwana occurs closely to the onset of the Parana LIP, the opening of the South Atlantic, and the formation of large sections of Seaward Dipping Reflectors (SDR) of basalt (Hinz et al.,1999), associated with large volumes of underplated basalts along both sides of the south Atlantic. Along the sheared margin of the south coast, delineated by the Agulhas Fracture Zone, large outpourings of basalt created the Agulhas Plateau (AP), and its associated extensions at the southern extremity of the Mozambique Ridge (MzR), Maud Rise (MR) and Maurice Ewing Bank (MEB) around 90-100 Ma, at the time when the Falkland Plateau is finally severed from Africa, and during which the direction of motion of the African Plate changes significantly (Chron 34i; Eagles, 2007, see text for further discussion). This is coincident with a period of intense uplift and erosion across southern Africa and a sharp peak in the number of kimbelite intrusions. Inset shows the location of LIPs (black circles 1-5) related to Gondwana disintegration (e.g. Hawkesworth et al., 1999; Jourdan et al., 2007) relative to the long-lived subduction zone along the convergent margin of southwest Gondwana; the outline of the present low velocity zone is shown in gray, with the present continents rotated back in their Gondwana position. The spatial coincidence implicates a geodynamic relationship between the long term subduction processes along this margin ( $>500 \mathrm{Ma}$ ) and the opening of the southern oceans through the formation of a number of plumes emplaced above a deep upwelling mantle low velocity zone (e.g. Le Pichon and Huchon, 1982), the remnants of which still resides beneath southern Africa and surrounding oceans today (e.g. Montelli et al., 2006; see text for further explanation). LIPs: 1= CAMP; 2= Cameroon-St Helena; 3= Parana-Etendeka; 4= Karoo; 5= Kerguelen. Figure modified from Stern and de Wit (2004).

basalts (CFB) with voluminous mafic underplating along both margin of the south Atlantic (Hinz et al., 1999; Trumbull et al., 2007 this volume; S. Neben, personal communications 2006 to 2007; Figure 4). This first event is followed by a period of quiescence for $>40$ Ma before a second period of fast cooling occurred between $~ 110$ and $\sim 90 \mathrm{Ma}$, and during which up to $4 \mathrm{~km}$ denudation took place along the coastal plains and up to $2 \mathrm{~km}$ from the top of the plateau. This event overlaps with the second major cooling episode documented along the south coast (e.g. $\sim 100$ to $\sim 80 \mathrm{Ma}$ ), not associated with rifting but instead overlapping with oceanic flood basalt activity during the formation of the Agulhas Plateau (Figure 4; Uenzelmann-Neben et al., 1999; Uenzelmann-Neben and Gohl, 2004; Gohl and Uenzelmann-Neben 2001). 
Episodes of increased cooling (and by inference exhumation/erosion) in the early and mid-late Cretaceous ( 100 to $\sim 65 \mathrm{Ma})$ can be traced regionally farther across southern Africa. For example, AFTA suggests increased denudation in the late Cretaceous ( $\sim 80$ to $\sim 60 \mathrm{Ma}$ ) removing $\sim 3$ to $4 \mathrm{~km}$ of overburden along the east and west coasts (eastern Natal, and Namibia, respectively), about 1 to $2 \mathrm{~km}$ from the eastern interior (Brown et al., 2000; 2002), and $>3.5 \mathrm{~km}$ in central Namibia at $\sim 70 \mathrm{Ma}$ (Raab et al., 2002; 2004). There is additional evidence of mid-Cretaceous cooling ( 100 to $\sim 90 \mathrm{Ma}$ ) as far north as northern Mozambique (Dassinnies et al., 2004).

Thus, increased denudation across southern Africa in the Cretaceous operated on a regional scale $(>1000 \mathrm{~km})$, and suggests that exhumation, and by inference uplift, was associated with dynamic mantle processes affecting the whole of southern to south-central Africa at that time. To understand what sustained this regional (Kalahari) epeirogeny, other factors must first be considered.

\section{Structure and stability of the southern African lithosphere}

The land surface of southern Africa was uplifted in the Mesozoic and is presently still in a complex stage of active, but slow peneplanation (King, 1967; Partridge and Maud, 2000; Bierman and Caffee, 2001), but with low vertical denudation rates $(<2 \mathrm{~m} / \mathrm{Ma})$, and horizontal escarpment retreat $(<10 \mathrm{~m} / \mathrm{Ma})$, as determined from cosmogenic dating of present day exposed surfaces (Flemming et al., 1999; Cockburn et al., 2000; Bierman and Caffee; 2001; Bierman and Nichols, 2004; Kounov et al., 2007).

Before the Mesozoic, southern Africa had a long history of repeated peneplanation for more than three billion years, during which it has retained its nearpresent lithosphere strength (or rapidly regained this after short lived thermal perturbations, e.g. Bell et al., 2003, Schmitz and Bowring, 2003), and by inference its stability (e.g. Doucouré and de Wit, 2003b and references therein). Whilst orogenic episodes have uplifted parts of southern Africa locally throughout its history (e.g. during the late Archean Limpopo orogeny, the Paleoproterozoic Kheis orogeny, the Mesoproterozoic Namaqua Natal orogeny, the lateNeoproterozoic Pan African Damaran-Gariep-Saldanian orogeny, and the Paleozoic Cape orogeny), major regional uplift/exhumation of the craton does not seem to have been extensive in time and space (see Tankard et al., 1982 for overview; Bell et al. 2003). For example, a regionally well-preserved near-horizontal Archean peneplanation surface ( $>1000 \mathrm{~km}$ across) that is in many places still covered by Archean shallow marine sedimentary rocks (the Transvaal Supergroup) shows that this base level surface has resided close to sea level for nearly three billion years until its Cretaceous uplift (Figure 5). To understand what controls this stability, that was established almost 3.0 billion years ago (e.g. Schmitz and Bowring, 2003; Schoene and Bowring, 2006, and references therein), and why it was only significantly disturbed regionally at the end Mesozoic, requires some discussion of the cratonic upper mantle lithosphere of southern Africa.

\section{The deep lithosphere of cratonic southern Africa}

The geology of southern Africa is built around the large Azanian Craton (joint Kaapvaal-Zimbabwe Craton, Figure 5). Cratons are generally Archean regions of extreme long term stability (Clifford, 1966; Burke as reported in Isacks et al., 1973; Jordan, 1975; 1988; Flowers et al., 2004; Schoene and Bowring, 2007). The Azanian craton is no exception (Tankard et al., 1982; de Wit et al., 1992; Moser et al., 2001; Schmitz et al., 2004; Schoene and Bowring, 2007). Like most other Archean continental blocks, this craton (which in aerial extent and lithospheric depth dominates all other younger tectonic domains) is underlain by thick lithospheric mantle that is chemically relatively depleted and buoyant compared to younger surrounding continental lithosphere (Jordan 1975; 1988; Vinik et al., 1996; Parman et al., 2004; James et al., 2004; Niu et al., 2004). The chemical characteristic of this thick mantle lithosphere has been pivotal in buffering the tectonic and thermal history of southern Africa as a whole (Doucouré and de Wit, 2003a; b; Kaban et al., 2003; Micheat et al., 2007, and references therein). Nevertheless, episodically secondary (metasomatic) processes have significantly affected the chemistry, mineralogy, and density of the Kaapvaal cratonic lithosphere to varying degrees subsequent to its initial formation more than $3.2 \mathrm{Ga}$ (de Wit et al., 1992; Bell et al., 2003; le Roex et al., 2003; Bell and Moore, 2004; Becker and le Roex, 2004; Harris et al., 2004; James et al., 2004; Schmitz et al., 2004; Shirey et al., 2005; Michaut et al., 2007). These have likely influenced at least second order epeirogenic features (Doucoure and de Wit, 2003a; b; Kaban et al., 2003).

The thickness of the subcontinental lithosphere beneath southern Africa varies significantly, even locally (Chevrot and Zhao, 2007). Beneath the Azanian craton, the thickness calculated from seismic velocity analyses varies between 150 and $400 \mathrm{~km}$ depending on the type of analyses and arrays used. For example, James et al. (2001) and Fouch et al. (2004), using near-vertical body wave analyses, find that the lithosphere varies in thickness between 250 and $400 \mathrm{~km}$, but predict that it is probably closer to $250 \mathrm{~km}$ (James et al., 2004) or $300 \mathrm{~km}$ (Wittlinger and Farra, 2007). Others using surface and Rayleigh wave data find the lithosphere to be at most 200 km (Ritsema and Van Heijst, 2000; Ritsema et al., 1999; 2004; Priestley et al., 2006; Merrer et al., 2007). Converted P-S waves studies (Stankiewicz et al., 2002) reported seismic velocities $\sim 6 \%$ higher compared to global model averages for the upper $300 \mathrm{~km}$, followed by a lower velocity section down to $400 \mathrm{~km}$, with speeds of $\sim 3 \%$ higher than the same global average model. Ritsema and Van Heijst (2000) also report that shear 
5A

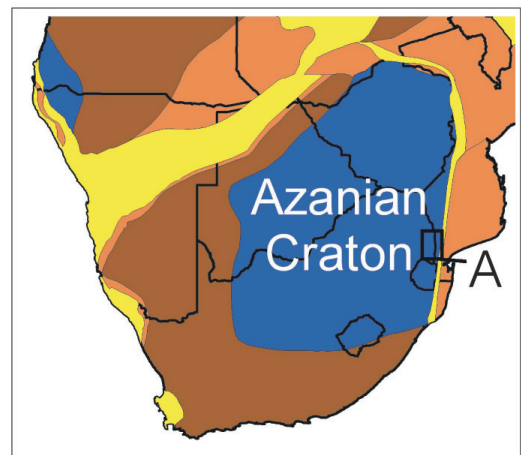

------- Cretaceous peneplanation

Palaeozoic-Mesozoic Cover $(0.35-0.18 \mathrm{Ga})$

Karoo Supergroup

------ Palaeozoic peneplanation

Archaean-Palaeoproterozoic Cover $(<2.7 \mathrm{Ga})$

Transvaal Supergroup

--------Archaean peneplanation

Archean Basement (>3 Ga)

Gra nitoids

Gre ens tone Belt

$5 B$
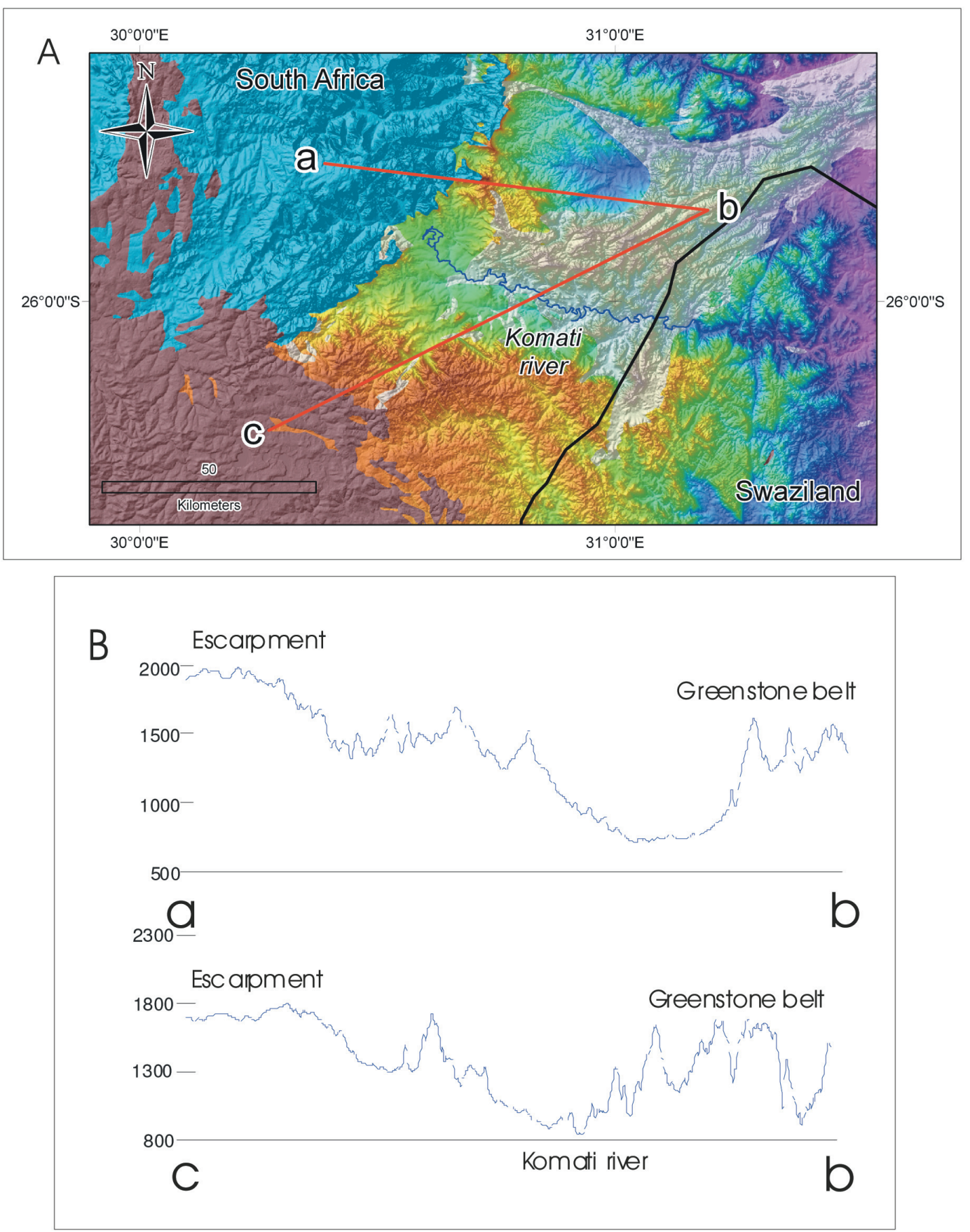


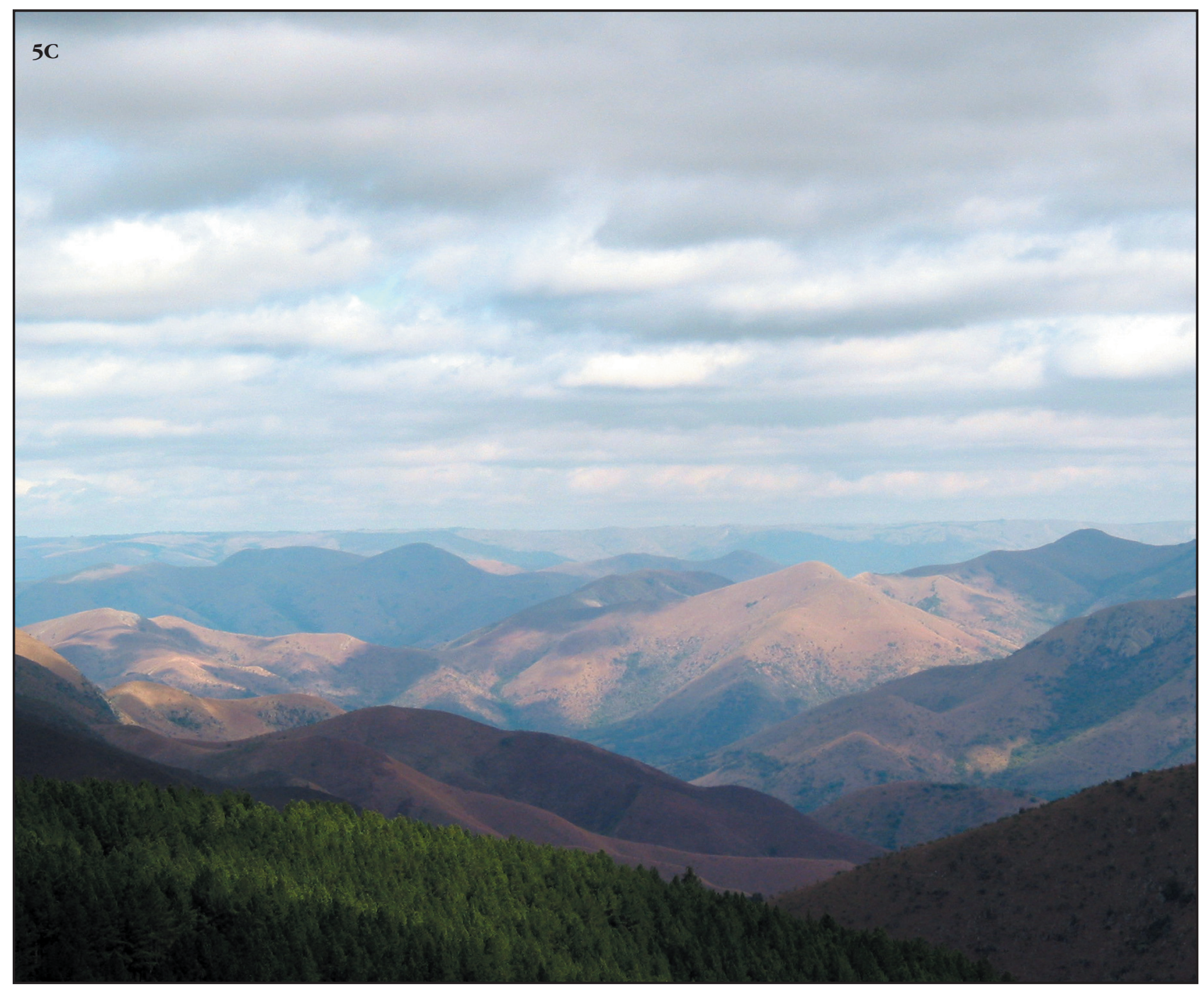

Figure 5. (A) Geologic map along and (B) cross sections constructed across the eastern margin of the exhumed, $\sim 2.9$ to $~ 2.8$ Ga peneplain that cuts across the Archaean granite-greenstone basement of the Azanian Craton. This surface of the Kalahari Plateau can be traced across almost the entire craton that is still partly covered by subhorizontal $\sim 2.7$ to $\sim 2.6$ Ga marine carbonates and quartzites of the Transvaal Supergroup (e.g. in the northwest of $\mathbf{A}$ ), and in turn by subhorizontal Palaeozoic Karoo Supergroup (in the southwest of $\mathbf{A}$ ). This Archean peneplain has been repeatedly covered by thin marine transgressions (last time at $\sim 300 \mathrm{Ma}$ ) and episodically exhumed, but is now in the process of erosion along the escarpment that formed in response to the Mesozoic uplift of the Kalahari Epeirogeny. The Komatii River has sculptured a deep valley (natural 'donga') into the Archean basement, whilst inheriting its meandering geometry from initially flowing across the subhorizontal peneplain. Note that the highest peaks of the mountainous region (mostly resistive vertical dipping quartzites and cherts) of the greenstone belt, reached close to the surface of the Archean peneplain. The long history and preserved subhorizontal disposition of the exhumed peneplain attests to the long term stability of the southern African lithosphere. Cross sections in $\mathbf{B}$ are constructed along the red lines shown in A. Elevation data is from the Shuttle Radar Topography Mission (SRTM) 90 m resolution dataset (available at http://srtm.csi.cgiar.org/SELECTION/inputCoord.asp). Inset: Tectonic elements of southern Africa showing the extent of the Archean Azanian Craton (> 2.5 Ga; blue) embedded in the Mesoproterozoic Kalahari Shield (>1.0 Ga; brown) that was enlarged farther still in Neoproterozoic times ( $>0.5 \mathrm{Ga}$; yellow). (C) Photo showing subhorizontal exhumed Archean peneplain (horizon), taken from top of a ridge within the greenstone belt $\sim 1 \mathrm{~km}$ north of the Komatii River, and looking west along the line of the section (b-c).

wave velocities in the upper $\sim 200 \mathrm{~km}$ are $6 \%$ above their global model, decreasing to $1 \%$ higher than these models from 200 to $400 \mathrm{~km}$. Various relatively weak lowvelocity zones (LVZ) have also been detected, at 220 to $350 \mathrm{~km}$ (e.g. Freybourger et al., 2001), between 160 and $330 \mathrm{~km}$ (Priestley, 1999), and 300 and $400 \mathrm{~km}$ (Stankiewicz et al., 2002). Thus, there is as yet no consensus amongst the seismologists about the precise depth and nature of the lithosphere beneath cratonic
Africa (and the 3-D variability that clearly exists within it; e.g. Chevrot and Zhao, 2007 and Figure 6). However, all are in agreement that a minimum depth down to $\sim 160 \mathrm{~km}$ of relatively cool, buoyant and chemically depleted Archean mantle is unavoidable, in agreement with the available petrological data from mantle xenoliths and diamond inclusion studies (Boyd and Gurney 1986; Boyd, et al., 1985; Bell and Moore, 2004; Shirey et al., 2005; le Roex et al., 2006) and heat flow 


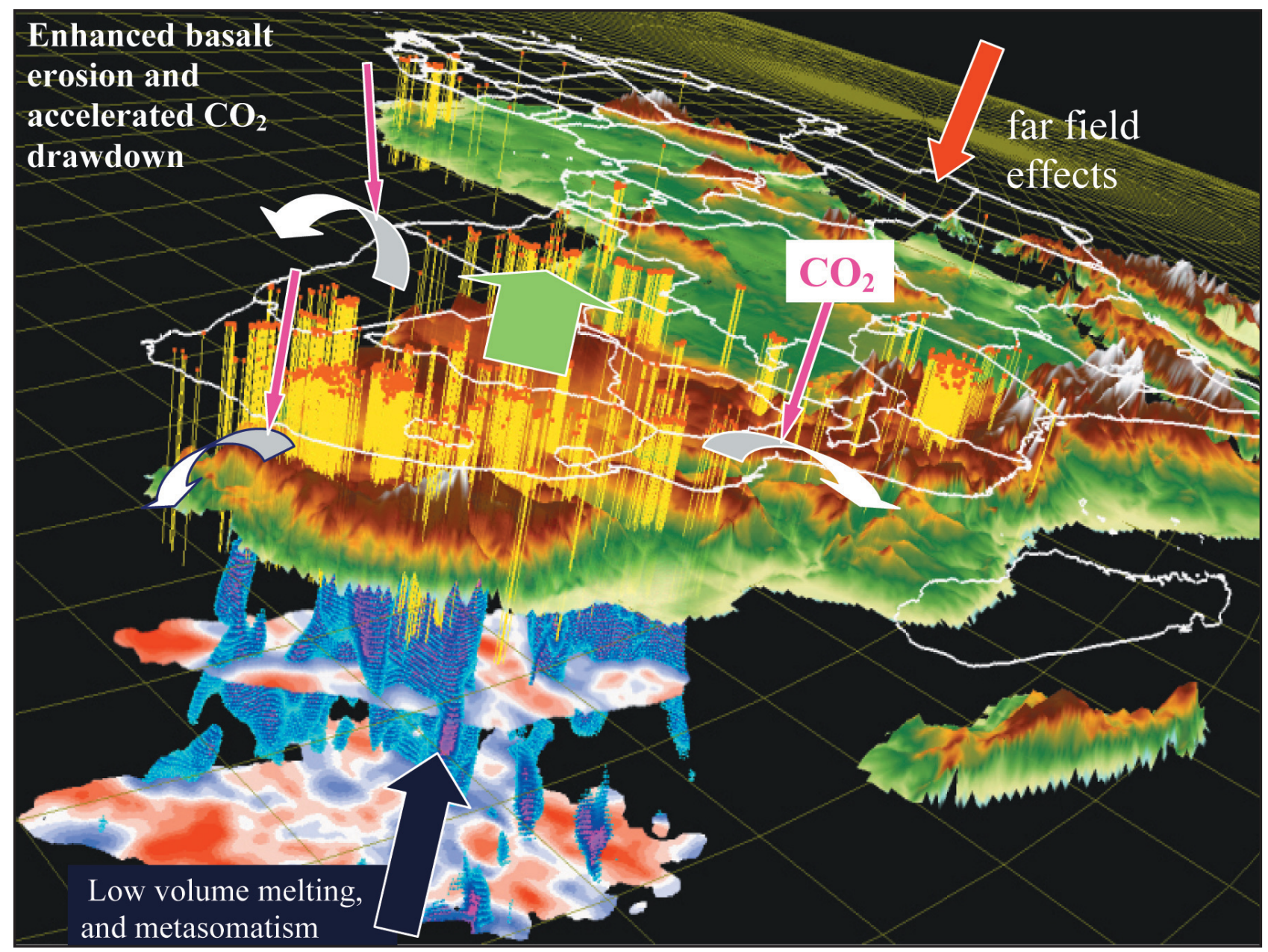

Figure 6. 3-D image showing the African surface elevation, and known kimberlites intrusions (vertical yellow lines) that extend down into the underlying lithospheric mantle. Seismic P-wave velocity data is shown with velocities shaded by standard deviation from the mean (zero velocity=white; fast waves=blues; slow waves= reds), illustrated at the 200 and $400 \mathrm{~km}$ from surface depth layers. Also shown schematically (red arrow) is the relative depression of Mesozoic northern Africa during collision with Europe and subduction-roll back of the Tethys oceanic lithosphere beneath Africa, speculated here to induce far-field tectonic uplift, plate reorganisation and low- volume partial melting below southern Africa and surrounding oceans ('surfboard effect' creating 'top down epeirogeny'). Broad arrows, representing the resultant Mesozoic exhumation (green) and erosion (grey-white) of the Kalahari highlands, removing a carapace of 2-6 km of cover, including a substantial volume of Karoo basalts, at a rate in excess of $0.5 \mathrm{~km}^{3} / \mathrm{yr}$, with a high rate of $\mathrm{CO}_{2}$ sequestration, resulting in global climate cooling (see text for further information). Figure is modified from the front cover of SAJG Kaapvaal volume 107 that was created by Dave Apter, De Beers Africa Exploration Group, 2004.

data derived from measurements and extrapolation from xenoliths data in kimberlites (Micheat et al., 2007).

Away from the cratonic lithosphere 'keels' the mantle lithosphere beneath younger terranes is generally thinner $(<120 \mathrm{~km})$, warmer and chemically less depleted. The lowermost sections of this mantle are also affected by metasomatism and partial melting during episodic fluid influxes (e.g. Doyle et al., 2004).

Below $200 \mathrm{~km}$ the cratonic lithosphere (and possibly also that beneath the surrounding younger terranes) may be more complicated, a result of a variable mixture of remnants of old mantle with refertilised, veined and metasomatised sections interspersed with younger magmatic materials (O'Reilly and Griffith, 1996; 2006; Shen and Blum, 2003). Such thermally and chemically modified deep Archean lithospheric mantle may reach depths of at least $300 \mathrm{~km}$ and possibly to the $410 \mathrm{~km}$ discontinuity (Stankiewicz et al., 2002) and even deeper (Gu et al., 1998; Blum and Shen 2004), in which case the heat and metasomatising fluids may have been derived from the mantle transition zone if, for example, this zone was at some stage heated from below (e.g. Ringwood, 1967; 1982; 1991; Nicolaysen 1985a; b; Irufine and Ringwood, 1993; Blum and Shen 2004; Mierdel et al., 2007). Such upward fluid penetration and associated metasomatic zone refining have the potential to change the buoyancy of the overlying lithosphere.

\section{Potential causes for the Kalahari epeirogeny}

The bimodality of the normalized Cretaceous African topography implies that uplift beneath southern Africa pre-dates the Cenozoic and that the associated alkaline igneous activity suggests this may have had an origin linked to deep mantle processes. We refer to this as 
'bottom-up' epeirogeny. This is distinctly different from a model related to lateral variations in upper mantle temperatures that drive local convection and partial melting that requires no a priori mantle plumes (e.g. 'topside tectonics' of Anderson 2000, and references therein), and may even be driven by lithosphere deformation during plate reorganisation (see below). In the Anderson model, locations and volumes of intraplate volcanism are controlled by lithosphere architecture and its stress-strain response to far-field plate reorganization that induce pressure-release melting and in turn force epeirogeny. For example, lateral transmission of far-field forces that instigate feed-back mechanisms such as diapirism and related thermal perturbations (via metasomatism, volume increase, partial melting) with deep seated sources has been suggested to be the cause of the uplift of the Rhenish Massif (400 to $600 \mathrm{~m}$ ) ahead of "Alpine push" during the Alpine orogeny (Neugebauer et al., 1983). Similar suggestions have been advanced for an Alpine induced uplift and rifting in East Africa; and even for the formation of the Pacific 'superplume' (Vaughan and Scarrow, 2000). We refer to this here as 'top-down' epeirogeny. Below we briefly highlight some observations with which to evaluate 'top-down' and 'bottom-up' mechanisms to explain the uplift and volcanism of southern Africa in the Cretaceous.

\section{Large Igneous Provinces (LIPs) and basaltic underplating.}

Cretaceous uplift might be related to basaltic magmatism that occurred at $\sim 180 \mathrm{Ma}$ throughout southern Africa and Antarctica, and again at $130 \mathrm{Ma}$ in Namibia (Figure 4), particularly if it can be shown that contemporaneous emplacement of mafic material occurred near the crustmantle boundary. For example, $\sim 15 \mathrm{~km}$ of such material in the lowermost crust would produce $\sim 2.7 \mathrm{~km}$ of permanent uplift assuming a thermal time constant for the lithosphere of $\sim 60 \mathrm{Ma}$ (McKenzie, 1984)

The early magmatic event related to the KarooFerrar LIP (Large Igneous Province) occurred between 174-184 Ma during the first breakup between east and west Gondwana, about 20-30 Ma before the initial opening of the Indian Ocean and the Weddell Sea (Cox, 1989; Storey, 1995; Storey and Kyle, 1997; Duncan et al., 1997; Hawkesworth et al., 1999; Storey et al., 1999; 2001; Elliot and Fleming, 2000; Reeves and de Wit, 2000; Jokat et al., 2003; Eagles and König, 2007; Jourdan et al., 2007). The large thermal anomaly presumed to underlie the Karoo-Ferrar LIP (Marsh et al., 1997; Elliot and Fleming, 2000) may have initiated substantial uplift and exhumation across southern Africa (Cox, 1989) but this is not recorded in FTA dates of continental rocks or any basin analyses to date. The absence of such ages is consistent with a limited thickness of Karoo basalts $(<2 \mathrm{~km})$ and the intrusion of contemporaneous sills that directly underlie them, suggesting that most of the Karoo magma was emplaced near surface and not in the lowermost crust (e.g. Chevallier and Woodford, 1999; Svenson et al., 2006; Jourdan, et al., 2007). This is supported by a number of seismic studies that have all reported a sharp crust mantle boundary transition below a felsic lower crust beneath most of the cratonic lithosphere, directly beneath a substantial part of the Karoo LIP. Thus, there is no seismic evidence of regional basaltic underplating associated with the Karoo LIP in southern Africa (Durheim and Mooney, 1994; Nguuri et al., 2002; Stankiewicz et al., 2002; de Wit and Tinker, 2004; Nair et al., 2006; Wittlinger and Fassa, 2007), and therefore no associated buoyancy uplift should be expected as a long term consequence of its emplacement (c.f. McKenzie, 1984). Lack of substantial basaltic underplating is also consistent with the preservations of Archean-Proterozoic diamonds in the cratonic keel (Boyd et al., 1985; Shirey et al., 2005); and with the FTA indicating a lack of substantial exhumation and erosion of the basement underlying this LIP. Perhaps, lateral flow of melt derived from a deep mantle source occurring at shallow crustal levels (c.f. Ebbinger and Sleep, 1998) is a plausible cause for this widespread (Karoo) near surface intrusive-extrusive igneous activity (Chevallier and Woodford, 1999; Svenson et al., 2006)

The second magmatic event (Parana-Etendeka LIP) occurred just prior to the opening of the South Atlantic (Hinz et al., 1999; Stern and de Wit, 2004; König, 2006; Eagles, 2007; Trumbull et al., 2007. South from this LIP centre, seismic reflection and refraction studies have identified seaward-dipping reflectors along both sides of the South Atlantic, indicating large volumes of nearsurface basalts, and vast contemporaneous volumes of mafic underplating near the crust-mantle boundary for nearly $2000 \mathrm{~km}$ along the entire continental margin of the west coast of south Africa, as well as the adjacent margin of South America (Hinz et al., 1999; Trumbull et al., 2007; S.Neben personal communications 2006 to 2007; Figure 4). This provides a likely explanation for both the late Jurrasic-early Cretaceous AFTA-constrained exhumation event recorded along the west coast (Raab et al., 2002; Kounov et al., 2006; and in preparation), and its absence from similar studies along the south and east coasts (Indian Ocean).

Other younger continental and oceanic flood basalts warrant consideration as potential influences on the two major subsequent episodes of exhumation. These include the $\sim 120$ Ma Kerguelen hot spot, and the $\sim 90 \mathrm{Ma}$ Marion hot spot with its extensive magmatism along the Madagascar ridge. These magmatic events are synchronous with the two episodes of uplift/exhumation recorded by FTA, but the hot spots were a long distance away from southern Africa at the time of their activity. Their influence is therefore likely to be negligible. By contrast, the oceanic Agulhas Plateau ( 100 to $\sim 80 \mathrm{Ma}$ ), and its likely extensions preserved along the southern parts of the Mozambique Ridge, the Maud Rise, and the Maurice Ewing Bank adjacent to the Falkland Plateau (Gohl and Uenzelmann-Neben, 1999; Jokat et al., 2003; Uenzelmann-Neben and Gohl, 2004; 


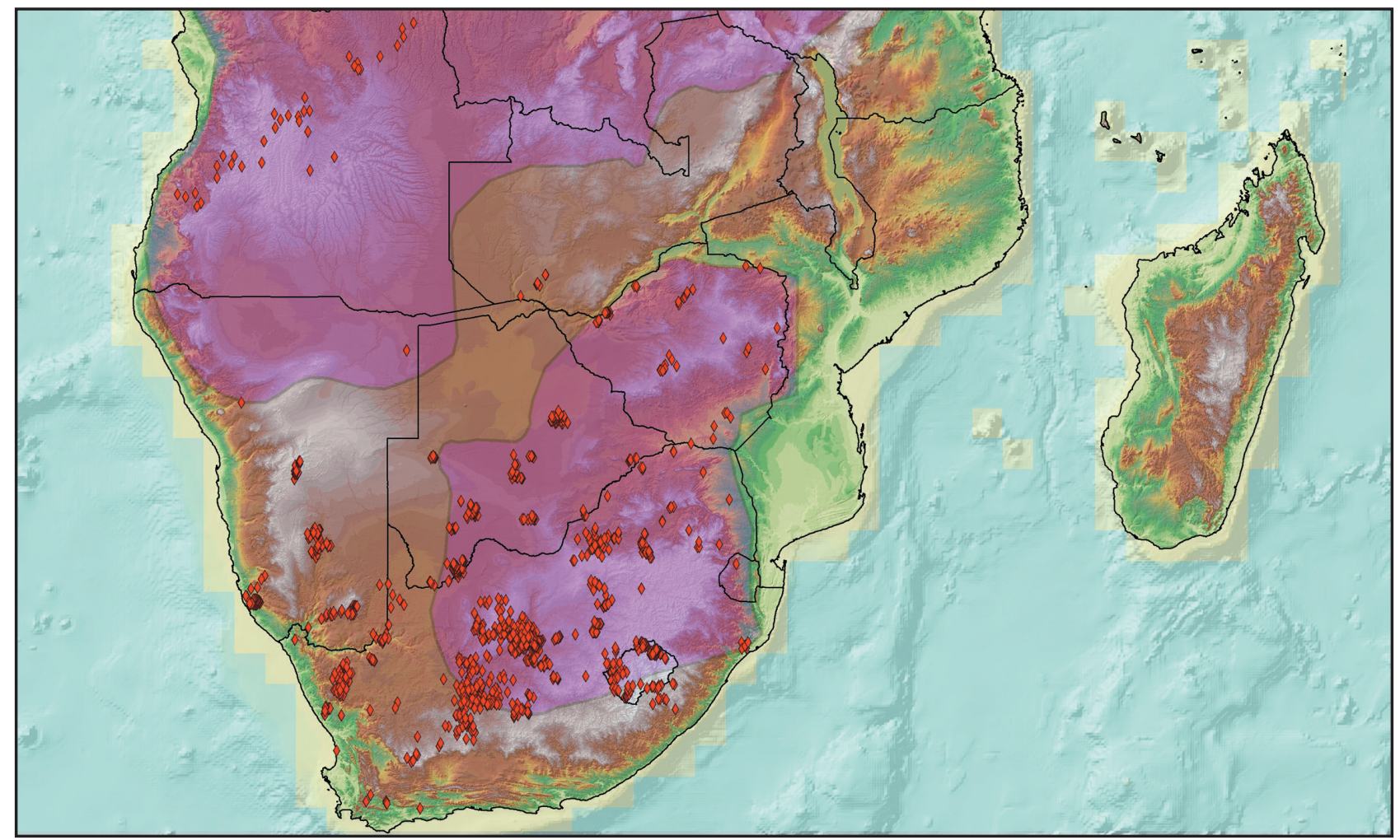

Figure 7. Regional distribution of kimberlites (red diamonds) shown on the topographic image of southern Africa. Recent discovered kimberlites are not shown, nor are all the know kimberlites of central Africa (modified from Jelsma et al., 2004; for a more detailed age differentiated distribution of these kimberlites, see Figures 7 a to $\mathrm{c}$ in Jelsma et al., 2004). Note the sub-linear alignment of the kimberlites in Angola with the Walvis Ridge. Purple areas outline stable Precambrian regions: southernmost = Azanian Craton (> 2.5 Ga); northernmost $=$ Central African Shield (>1.0 Ga).

Uenzelmann-Neben et al., 2004), closely flanked the sheared south-coast continental margin of southern Africa at the time of the first major uplift episode recorded here. This is also a time of distinct change in spreading direction in the South Atlantic (e.g. chron C34i $\sim 102$ to $\sim 90 \mathrm{Ma}$; Eagles, 2007) close to the time that the Falkland Plateau cleared the southern tip of Africa and broke-off its last connection to the African continent. However, the uplift of southern Africa is regionally extensive, and it is unlikely that this could be caused by the heat and magma source of the Agulhas Plateau alone. Other igneous events therefore warrant scrutiny.

\section{Punctuated kimberlitic magmatism across soutbern Africa}

Kimberlites have intruded southern Africa since the Archean, but their emplacement frequency has been most intense over a sustained period of $\sim 150$ million years in the Mesozoic. This eruption frequency is clearly reflected in a dense regional distribution of kimberlites, carbonatites and other and related rocks across southern African (Figure 7, Skinner et al., 1992; Jelsma et al., 2004). The spatial and temporal distribution of these rocks has frequently been related to: 1. mantle plumes, and hot spots; 2. rifting of continents; 3 . major faults or basement trends related to oceanic fracture zones; 4. temporal variations in deviatoric stresses related to changes in the motion vector of the African plate during the Cretaceous.

The last two best fit the spatial arrangement and age data of the kimberlites (Jelsma et al., 2004). A study of more than 1300 kimberlite occurrences in Southern Africa in relation to regional geological and geophysical data shows that there is a statistical probabability of a pronounced structural control on the location of these rocks (Jelsma et al., 2004, Basson and Viola, 2004). Some have attributed the trends to hot spot tracks (e.g. le Roex, 1986; Skinner, et al., 1992; Harris et al., 2004), but the scatter in age distribution does not favour such an interpretation (Jelsma et al., 2004). The distribution of clusters is statistically governed by four dominant trends parallel to regional fractures (referred to as cryptic corridors when on transcontinental scale) that may be controlled by deeper shear zones in the lithospheric mantle (Fuller, 1972; Vearncombe and Vearncombe, 2002; Jelsma et al., 2004). These are important trends within the architecture of the African lithosphere that, therefore, may have controlled kimberlite emplacement and possibly magma genesis during changing stress regime within a plate tectonic framework. Resistance during reorganization of plate motions may cause the local state of stress to change rapidly, causing the deep lithospheric faults to be the loci of extension or compression (Jelsma et al., 2004). However, there are only few dated kimberlites directly associated with the 


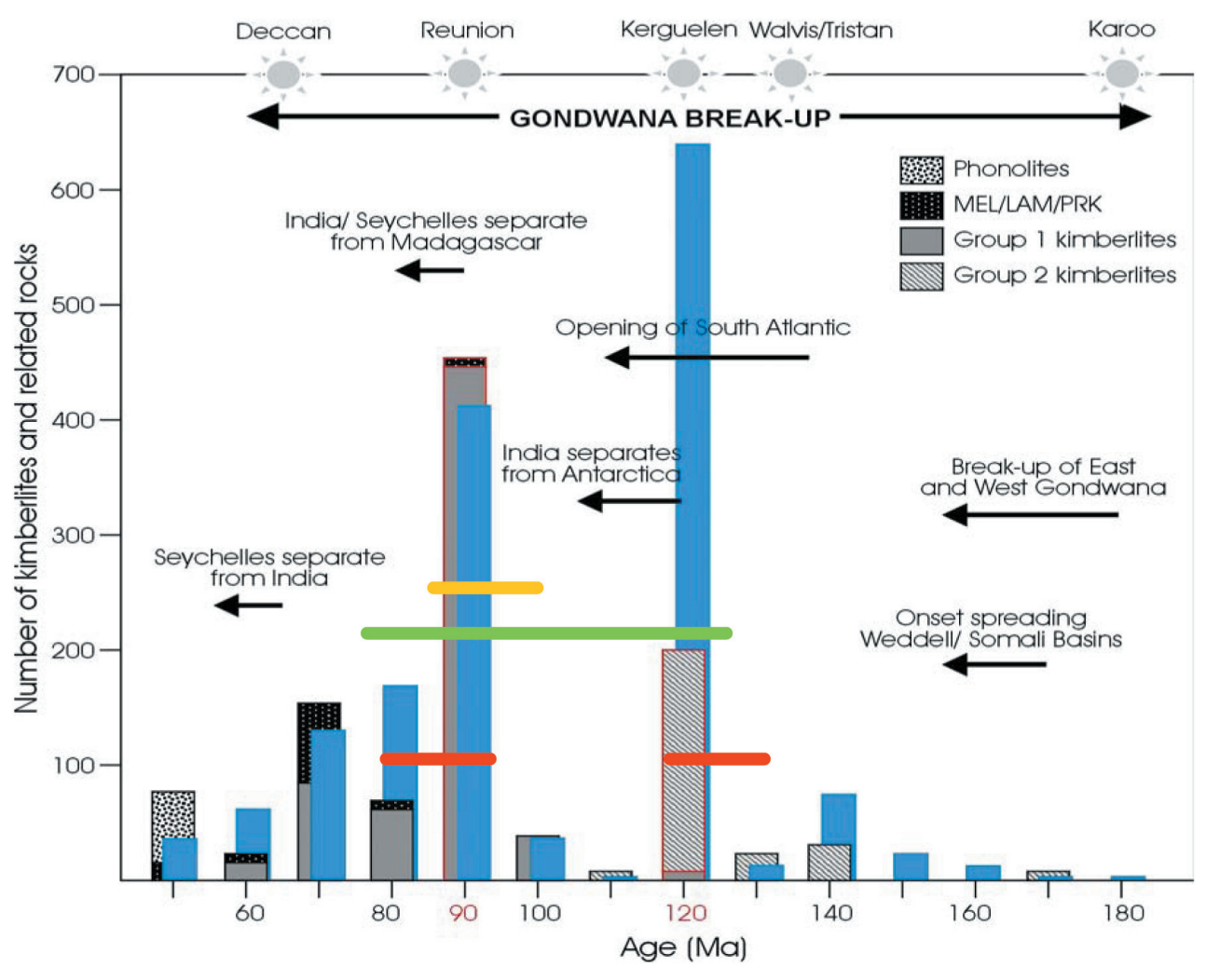

Figure 8. Age-frequency distribution of dated kimberlites in southern Africa (greys) and south-central Africa (blue). Note the correlations between the short episodes of punctuated kimbelite intrusions and the two main uplift/exhumation phases (red bars) of the Kalahari epeirogeny, the formation of the Agulhas oceanic plateau (yellow bar) that overlap in time with accelerated motion between Africa and Europe (green bar), and plate reorganisation in the South Atlantic. Names and times of major plume activity shown at the top (modified from Jelsma et al., 2004, Tinker, 2005 and unpublished data from de Beers; see text for further explanation).

onset of Gondwana break-up and the early formation of the Indian Ocean $(\sim 170$ to $\sim 140 \mathrm{Ma})$ and the Central Atlantic Ocean ( 180 to $\sim 160 \mathrm{Ma})$, and their associated hotspot activity recorded in the Karoo/Ferrar ( 180 Ma) and CAMP ( $200 \mathrm{Ma}$ ) flood basalts, respectively (Stern and de Wit, 2004; see Figure 4). Most kimberlites in Africa (and South America) therefore intruded well after the early growth of the Indian Ocean and the early opening phase of the Atlantic Ocean (Reeves and de Wit, 2000; Jokat et al., 2003; König 2006; Eagles, 2007; Eagles and König, 2007).

Most kimberlites in southern Africa are of midCretaceous age $(\sim 125$ to $\sim 80 \mathrm{Ma})$ and at least two distinct episodes with a very high rate of kimberlite intrusions are evident in that period: $>450$ kimberlites at $\sim 90 \mathrm{Ma}$, and >200 kimberlites at $\sim 120 \mathrm{Ma}$ (Doucouré and de Wit 2003a; Jelsma et al., 2004; Tinker 2005; Tinker et al., 2007 in review; Figure 9). These two distinct 'spikes' of kimberlite intrusion are thus synchronous with the two main regional episodes of accelerated onshore denudation/offshore sediment accumulation.

Kimberlite 'peppered' shield areas in Africa and South America (Kalahari and Congo Shields with their embedded Azanian and central African cratons, the West
African Shield with the Leo Man Craton, and the Sao Francisco Shield with the Archean craton around Belo Horizonte, respectively; e.g. de Wit et al., 2007 in press) are all affected by significant Mesozoic-Cenozoic epeirogenic uplifts. However, extensive kimberlite intrusions are not synonymous with regional uplift of all Precambrian Shields with embedded old Archean cratons. For example, neither the Siberian Anabar Shield of Russia (with Paleozoic and early Mesozoic kimbelite fields) nor the Slave province of Canada (Mesozoic and Cenozoic kimberlite fields), nor the Pilbara-Yilgarn region of west Australia (mainly Proterozoic kimberlites), display such epeirogenesis; indeed the latter is still an exhumed ancient peneplain relatively close to sea level (Twidale, 1994). Thus 'bottom-up' epeirogeny cannot explain all the relevant geologic observations. The additional requirement that drives the uplifts, therefore, remains elusive. An important observation in southern Africa is that the compositionally distinct sources required for the generation of kimberlites and related rocks are often also associated with recurring flood basalts of various ages (e.g. LIPs of the Kalahari craton: Ventersdorp at $\sim 2.7 \mathrm{Ga}$; Bushveld at $\sim 2.0 \mathrm{Ga}$ and Karoo at $\sim 0.2 \mathrm{Ga}$; see 
Tankard et al., 1984, for overview). This implies that at least some of these sources reside in their subcontinental mantle-lithosphere, although there is no universal agreement on this, as overall the chemistry best represents that of intraplate OIBs (e.g. Carlson et al., 2006). Nevertheless there is no a priori necessity to appeal to a deep-mantle source to supply the geochemical characteristics of these magmatic rocks (Carlson et al., 2006). What other aspects may then play an important role in liberating these fluids if they have an upper mantle source, and what additional effects might this have had on initiating and sustaining the end Mesozoic epeirogeny?

\section{Far field stresses related to collision and obduction along the northern margin of the African Plate}

There is a close temporal relationship between the initiation of new spreading regimes in the north and central Atlantic Ocean and convergent tectonics between Africa and Europe (Smith, 1971; 2006; Dewey et al., 1972; 1989). For example, the formation and emplacement of supra-subduction zone (SSZ) ophiolites in the western Mediterranean along the convergent margins flanking the African and Eurasian plates occured during episodes of fast and slow convergence between these two plates, respectively. These episodes can be linked to significant changes in the spreading regimes recorded in the magnetic anomaly patterns of the North Atlantic Ocean (e.g. sudden ridge jumps leading to the opening of North Atlantic, and the Labrador Sea). During the two episodes of regional ophiolite emplacements, the rate of convergence between the Africa and Eurasia plates comes to a near stand-still (Figure 1).

The obduction of Tethyan oceanic lithosphere (as ophiolites) onto continental Europe took place in two main phases: late-Jurassic and late-Cretaceous. Both episodes are synchronous with reduced rates of motion between Africa and European plates (e.g. at $\sim 140$ to $125 \mathrm{Ma}$ and $\sim 75$ to $55 \mathrm{Ma}$ ), as determined from the Atlantic spreading data (Smith, 2006). Separating these episodes of slow motion are periods with more than a 3 -fold increase in the rate of motion between the two plates (e.g. $\sim 10 \mathrm{mmyr}^{-1}$ between $\sim 120$ and $\sim 75 \mathrm{Ma}$ ). Before the onset of the first slow-motion episode the relative rate of fast-motion between the Africa and Eurasia is estimated to have been $\sim 25 \mathrm{mmyr}^{-1}$; today it is measured to be $\sim 5 \mathrm{mmyr}^{-1}$ (Reilinger et al., 2006).

The emplacement of the ophiolites across the Eurasian plate was driven by the overall attempt to subduct a relatively active Eurasian continental margin across the African passive continental margin and its attached Mesozoic ocean floor of the proto-African plate. This is still ongoing today, driven by a large component of Africa-directed slab retreat (e.g. Carminati et al., 1998; Wortel and Spakman, 2000; Faccenna et al., 2004; Hafkenscheid et al., 2006). Despite the complexities related to the formation and rotation of intervening microplates, the obduction events influenced the relative motions between the Africa and European plates, and in turn the spreading rates in the Central and North Atlantic (Smith, 2006). A first-order observation is that the tectonic emplacements of the Mediterranean ophiolites (and episodes of peak collisions) were followed by the sudden onset of fast, orthogonal motion between Africa and Europe (Figure 1) that influenced spreading events (and thus passive pressure-release melting) in the Central and North Atlantic region. It is likely that such tectonic events in the Mediterranean also may have had other far-field effects on the African plate. For example, these events are synchronous, within the margins of dating errors, with the opening of the South Atlantic, and with asymmetric spreading rates and ridge jumps in the South Atlantic (e.g. König, 2006 and references therein; Eagles, 2007; Eagles and König, 2007). Perhaps such lithosphere-driven events even influenced partial melting in the upper mantle to initiate the thousands of small alkaline intrusions (e.g. kimberlites) and shallow mantle Anderson-style convection (c.f. Anderson, 2000).

Such plate reorganization and reactivations of fault zones may have allowed kimberlite fluids to repeatedly ascend through transcurrent faults and cluster within near-surface structures. Thus, many cryptic continental corridors are co-linear with fracture zones along the Atlantic and Indian continental margins of Southern Africa (Fuller, 1972; Vearncombe and Vearncombe, 2002; Basson and Viola, 2004; Jelsma et al., 2004;) that may have found their origin in events resulting from episodic changing motion of Africa relative to Eurasia (Jelsma et al., 2004). A sharp change in spreading direction and ridge jump (at Chron C34i) has recently been identified around $\sim 102$ to $\sim 90 \mathrm{Ma}$ (Eagles, 2007), related to the end of the diachronous phase of opening of the South Atlantic. This is precisely the same type/time of reorganization seen in the North Atlantic, which has been directly tied to the change in spreading rates between Europe and Africa (Smith, 2006; Figure 1).

There remain significant unknowns about the precise tectonic history of the Tethys ocean, particularly in the Jurassic, but in a broad sense the punctuated tectonic collision events in the Mediterranean may have had a profound far-field effect on the evolution of the oceanic lithosphere of the African Plate, including the opening of the South Atlantic, and perhaps small-scale partial melting and related metasomatism of its underlying mantle that, in turn, guided the punctuated kimberlite emplacement. But what was the source of the melts and fluids, and what additional role may they have played in such 'top-down' epeirogeny, given their propensity to form low density phases during pressure release?

\section{Metasomatism in the lithospheric mantle across soutbern Africa}

Volatile induced metasomatism is ubiquitously associated with kimberlite magmatism (Wyllie, 1979; 1987) and it has been recognized for several decades 
that metasomatism is geographically widespread beneath southern Africa (Gurney and Harte, 1980; Erlank et al., 1987; Gregoire et al., 2003; le Roex et al., 2003; Bell et al., 2003; Bell and Moore, 2004; Harris et al., 2004; Becker and le Roex, 2006). Such fluid activity has, therefore, also a long history within the mantle lithosphere of southern Africa, but particularly in the Mesozoic.

The primary cause of volcanism on Earth is pressurerelease melting of upwelling mantle (e.g. Maaløe, 2005; Phipps Morgan et al., 2004 and reference therein). For upwelling at rates of more than $\sim 10$ mmyr $^{-1}$ most of the heat in or out of the melting region is carried by the escaping melt. For small transport distances, slow meltmigration, and small degrees of melting, significant local heat transfer may take place, causing in situ melting and/or metasomatism of the wall rocks by volatiles and other relatively incompatible materials derived from the melt sources.

The thermal energy needed for lithosphere uplift due to an internal phase change (metasomatism) is two orders of magnitude lower than that needed for its thermal uplift (Smith, 1982). This implies that a Cenozoic uplift of $\sim 1.2 \mathrm{~km}$ of Africa could be driven by a phase change of $\sim 9 \mathrm{~km}$ eclogite to $\sim 10.2 \mathrm{~km}$ of basalt (with a relative density change from 3.4 to $3.0 \mathrm{~g} / \mathrm{cm}^{3}$ ) in the upper $30 \mathrm{~km}$ or so of the lithospheric mantle of Africa. Smith (1982) assumed that the heat pulse needed to drive this change was supplied to the base of the African lithosphere in the Mesozoic as it passed across the slightly hotter asthenosphere in a fixed plate tectonic reference framework, with uplift following about 60 to $\sim 50 \mathrm{Ma}$, given a thermal time constant (thermal diffusivity) of about 60 million years. However, xenolith studies suggest that the eclogite volume in the southern African cratonic lithosphere is small $(<1 \%$; Schulze 1989) and because the phase transition upon heating near the Moho will be to garnet granulite rather than directly to basalt, this is apparently not a significant factor that could have controlled the marked uplift history of southern Africa. However, this could be a more important factor in the off-craton regions where there is evidence for mafic material in the upper mantle and lower crust (Durheim and Mooney, 1994; Carlson et al., 2006). What then of the buoyancy effect of the associated volatiles?

Metasomatism is a thermo-chemical process preceding volcanism, and involves density changes in the lithospheric mantle of up to $6 \%$ (e.g. Neugebauer et al., 1983). In addition volume change associated with exsolution of $\mathrm{CO}_{2}$ from alkali-rich-silicate melts in the upper parts of the mantle lithosphere (about 80 to $90 \mathrm{~km}$ ) is about $34 \%$ per unit volume of magma (Phipps Morgan et al., 2004).

Igneous petrologists have long noted a direct relationship between $\mathrm{CO}_{2}$ in the mantle and the origin of kimberlites and carbonatitic magmas (Wyllie 1979; 1987; Berg, 1986; Becker and le Roex et al., 2003; Wilson and Head 2007). The source of the carbon (and kimberlite magma) remains a matter of debate, but is likely to be stored in substantial quantity in the upper mantle and/or in the upper mantle transition zone (e.g. Ringwood, 1967; 1991; Wyllie, 1978; Nicolayson 1985a; b; Sautter et al., 1991; Irufine and Ringwood, 1993; Shen and Blum 2003; Phipps Morgan et al., 2004, and references therein). Such carbon-rich magmas may infiltrate and metasomatise the lower cratonic mantle. Some may work their way up until they reach the depth at which $\mathrm{CO}_{2}$ exolves from the silicate melts, which may create the instabilities needed to induce transport of kimberlitic/carbonatitic magma to surface (Wyllie 1979, Nicolaysen, 1985; Dalton and Wood, 1993; Phipps Morgan et al., 2004). The subcontinental mantle of cratons is likely, therefore, to accumulate significant volumes of volatiles, including $\mathrm{CO}_{2}$, perhaps at a rate of up to seven atmosphere equivalents per million years (Phipps Morgan et al., 2004). Retaining such quantities of $\mathrm{CO}_{2}$ in the mantle lithosphere and/or expelling it into the atmosphere should induce significant density changes, perhaps sufficient to drive its episodic up and/or down motions of the lithosphere. Because $\mathrm{CO}_{2}$-rich mantle has a much lower solidus (melting) temperature than $\mathrm{CO}_{2}$-poor mantle (water has a similar effect, e.g. Wyllie 1979), these volatiles are therefore easily extracted from the asthenosphere in small volume melts. This could occur during heating from below, often inferred to be associated with plumes ('bottom-up' epeirogeny), or during far-field stresses that may induce small degrees of pressure release partial melting and metasomatism in the upper mantle that, in turn, causes 'top-down' epeirogeny. To explore this further, we first need a better understanding of the potential fluid 'storehouse' and volatile fluxes.

\section{Circum-Gondwana subduction flanking soutbern Africa during Gondwana times}

Several workers over the last three decades have suggested that the long history of subduction around the supercontinent Pangea and later along the palaeo-Pacific margin of Gondwana has affected the chemistry of its underlying mantle (Ringwood, 1967; 1991; Cox, 1978; Le Pichon and Huchon, 1984; Nicolaysen, 1985 a; b; de Wit et al., 1988; Gurnis, 1988, Gurnis et al., 2000; Fukao et al., 1994; van der Voo et al., 1999; Courtillot et al., 1999; Collins 2003; Stern and de Wit, 2004; Tappert et al., 2005 a; b). Subduction of oceanic lithosphere beneath Gondwana started by the early Paleozoic and was active intermittently for nearly $400 \mathrm{Ma}$. This was still ongoing beneath this large continent whilst it disintegrated between 200 and $\sim 120$ Ma (e.g. Cox, 1978; de Wit et al., 1988); and beneath South America it continues to do so (Oncken et al., 2006). The fate of the subducting slab(s) has been a matter of heated debate (e.g. Ringwood, 1967; Le Pichon and Huchon, 1984, Nicolayson 1985a, Davis 1993; Van der Voo et al., 1999; Van der Hilst et al., 1999; Conrad and Gurnis, 2003; Courtillot et al., 2003). Some of the volatiles and related trace elements released during subduction may have 
enriched the mantle transition zone, whilst most of the solid parts of the subducting lithosphere may have reached farther down to the core mantle boundary where, according to some models it has become part of the lower mantle superplume (e.g. Davis 1993; Courtillot et al., 2003, and references therein). There is some geological merit in these models, in that, rotated and plotted on a Gondwana map, the aerial extent of the present day supersplume covers the range of mantle plumes that have been implicated by many in the early breakup history of Gondwana (Figure 4, inset). If this were the case, then the superplume must have a chemical signature distinct from its surrounding mantle, and its cooling may have had a direct effect on local thermal processes in the core (e.g. Davis, 1993). In short, two mantle regions (the lower mantle and the transition zone) have both stored in them the recycled chemical mantle ingredients, including the volatiles, which are implicated in the formation of the LIPs that formed during Gondwana breakup (e.g. Sobelov et al., 2007, and references therein) as discussed above. What do the volatile components themselves reveal about their storage and origin?

Fluid inclusion studies on diamonds from kimberlites have shown that some of the metasomatizing fluids are brines (e.g. Izraeli et al., 2001). High Density Fluid (HDF) brines preserved in fluid inclusions in eclogitic and peridotitic diamonds from Koffiefontein kimberlite, for example, contain $\sim 30$ to 40\% water, $\sim 20 \%$ chlorine, $\sim 25 \%$ carbonates, $\sim 15 \%$ sodium and potassium with Ba and Sr, and $<4 \%$ silica (Izraeli et al., 2001). These fluids, including $\mathrm{CO}_{2}$, were likely therefore derived from subducted seawater, sediment or hydrated basalts emplaced as evolved subduction fluids beneath the southern Africa lithosphere before the opening of the South Atlantic, and were likely stored with other high PT components of continental crust and mantle silicates (e.g. hollandite, majorite, respectively) and carbon (e.g. Nishiyama et al., 2005, Tappert et al., 2005 a; b; Wirth et al. 2007) within the mantle transition zone as originally suggested by Ringwood (1967; 1991), Anderson (1979), Nicolaysen (1985a; b), Irufine and Ringwood (1993), and recently 'revived' (e.g. Shen and Blum, 2003; Blum and Shen, 2004; Tappert et al., 2005 a, b). From such a transient 'volatile storehouse', these fluids may have been episodically released to infiltrate, refertilise and partially melt the overlying depleted mantle lithosphere to yield small volume, alkaline magmas and kimberlites. The age of the fluids is not known. Thus these brine types may also represent an immiscible end-member derived from a more carbonatitic HDF, in turn derived through fractional crystallization from an alkali rich melt that may also be parental to kimberlites and lamproites (Klein-Ben David et al., 2006 a; b). Such carbonatitic HDF would percolate along grain boundaries and in veins through relatively large lithospheric mantle volumes. It is possible that both processes operated in tandem.

Either way, significant $\mathrm{CO}_{2}$-rich fluid flux into the mantle transition zone and from there into the overlying deep mantle lithosphere seems a good working model to drive metasomatism and episodic phases of epeirogeny, provided there is a heat source from below, or pressure release from the surface that ensures their release. What then is the ultimate fate of these fluids once liberated to reach the solid Earth surface during epeirogenesis?

\section{Epeirogenic feedback to climate}

Changes in the rates of $\mathrm{CO}_{2}$ degassing and sequestration are the main force of atmospheric $\mathrm{CO}_{2}$ and climate change at the geological time scale (Walker et al., 1981). The sudden release of mantle magma and $\mathrm{CO}_{2}$ into the ocean-atmosphere system during the Kalahari epeirogenic episodes may have directly influenced longterm runaway global climate change in the Mesozoic Cenozoic. For example, numerical modelling shows that the volume of $\mathrm{CO}_{2}$ released into the ocean-atmosphere system from basaltic magma during formation of LIPs such as the Deccan Traps will raise the global temperatures by $\sim 4^{\circ} \mathrm{C}$ through the sudden increase of greenhouse gas conditions (Dupré et al., 2003). There is good reason to believe that the sudden basalt outpourings of the even larger Karoo-Ferrar LIP would have influenced global climate to a similar if not greater degree, as would those of the Etendeka-Parana LIP and the oceanic island basalts of the Agulhas LIP. Under these circumstances, atmospheric $\mathrm{CO}_{2}$ concentrations will rise until climate conditions start to increase silicate weathering to compensate for the increases. Surprisingly, in the aftermath of the Deccan magmatism, the models predict that the increase in $\mathrm{CO}_{2}$ uptake by the basalt weathering has a negative feedback on the global temperatures in such a way that the final global atmospheric temperature stabilises at $0.5{ }^{\circ} \mathrm{C}$ lower than before the onset of the volcanism (Dessert et al., 2001; Dupré et al., 2003). The reasons for this are not fully understood. This type of modelling is still at an early stage and needs to be more inclusive of the roles of the biosphere, of the position of the continents on which the basalts occur, and the general climate conditions at the time of onset of the weathering (Ramstein et al., 1997; Fluteau, 2003). Nevertheless carbon is eventually transferred back from the atmosphere to the continental crust through silicate weathering sinks; and the uptake of $\mathrm{CO}_{2}$ by weathering of basalts is about 5 to 10 times as effective in sequestrating atmospheric $\mathrm{CO}_{2}$ compared to granites (Dupré et al., 2003),

In the mid Cretaceous, a large proportion of basalt must have been part of the 2 to $7 \mathrm{~km}$ of material that was eroded from southern Africa: the Karoo volcanics alone, for example, covered at least $65 \%$ of South Africa (e.g. $3 \times 10^{6} \mathrm{~km}^{2}$; Jourdant et al., 2007). With a thickness of near $2 \mathrm{~km}$, it is likely that more than $6 \times 10^{6} \mathrm{~km}^{3}$ basalt was removed within less than 10 million years (at a rate in excess of $0.5 \mathrm{~km}^{3} / \mathrm{yr}$ ) more than enough to significantly decrease the $\mathrm{CO}_{2}$ concentrations of the prevailing atmosphere. A conservative estimate of 


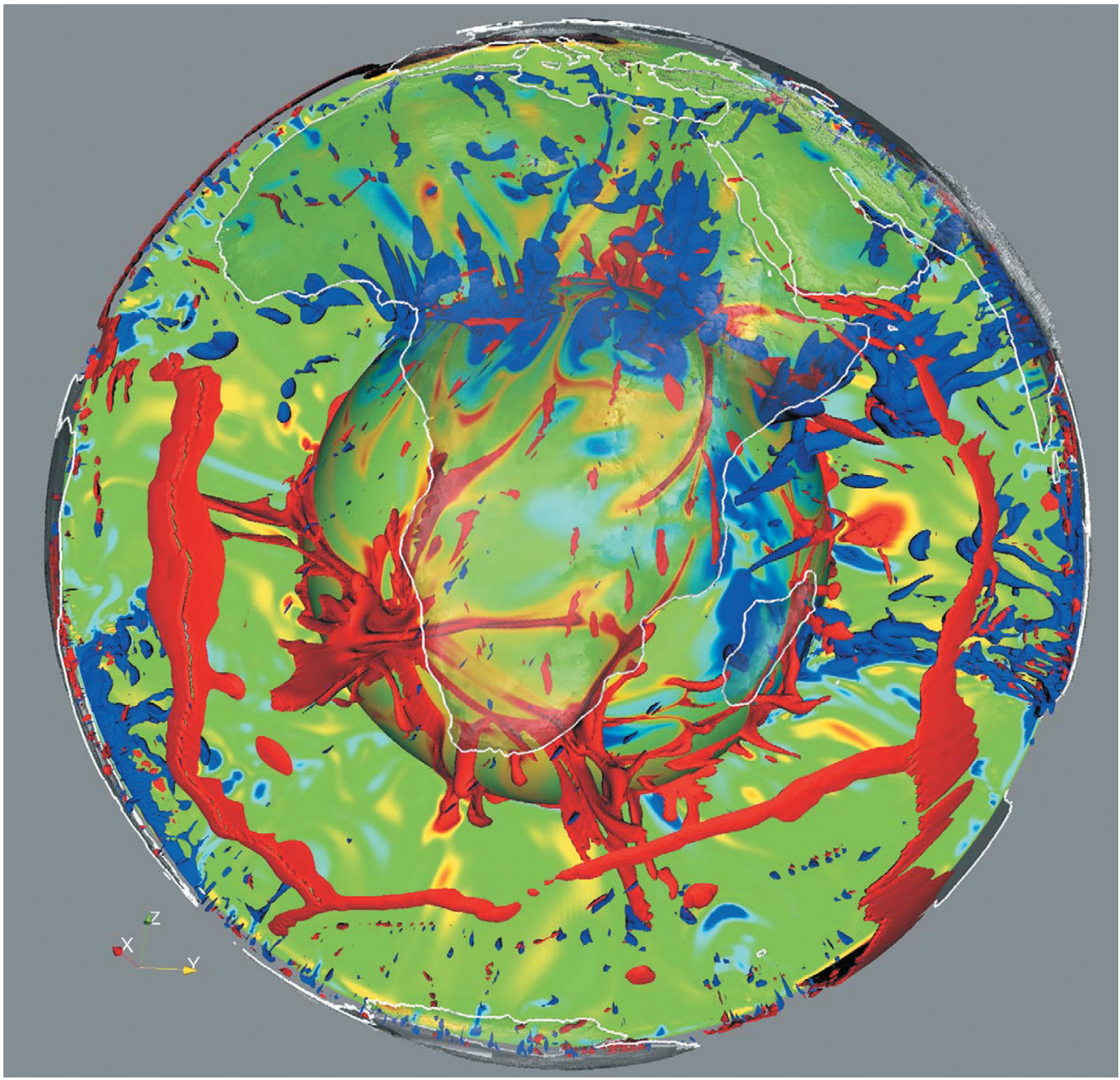

Figure 9. African hemisphere view of a geodynamic 3-D numerical model of the present 'solid' Earth, derived through time-dependant (dynamic) high-speed parallel computing. Mantle circulation models are computed at resolution of $20 \mathrm{~km}$, using TERRA convection codes and a number of parameters realistic for earth materials, heat production, phase changes, viscosity gradients, and plate motion histories to construct time-dependant mantle flow models using starting (initial) conditions going back to the Mesozoic (Bunge et al., 1998; 2002). The dynamic effect of mantle compressibility is incorporated using inelastic liquid approximations. The fine spatial scales of the mantle heterogeneities shown are highlighted using surfaces at $-500 \mathrm{~K}$ (blue) and $+300 \mathrm{~K}$ (red); in between values in green-yellow. The average temperature profile is the geotherm of the mantle circulation model that is almost adiabatic with a potential temperature of $1700 \mathrm{~K}$. Whereas these models still need considerable refining (like the general global climate models do), there is remarkable first order convergence between tomographic images, geological surface observations and this new-age numerical model. For example, what is striking in this particular image is the rise of hot materials (red) from broad areas at the core mantle boundary beneath southern Africa, through subvertical plume-like branches to upper mantle levels, where in turn they connect with mid-ocean ridges in the South Atlantic and Indian Oceans. The latter in turn connects to the spreading regimes in the Gulf of Aden and into the Afar. Also, thin long arms spread cross the core mantle boundary from which they rise along trains of irregular blobs, spouts and sheets to connect with areas at surface known to be hot spots in Africa (e.g. beneath east Africa, Tibesti, southern Darfur, Cameroon, etc.). Also the line of Cretaceous kimberlites that extends from the central Democratic Republic of Congo to the Angolan coast (see Figure 7), and from there connects through the Walvis ridge to the Mid South Atlantic ridge, runs parallel to a northeast trending hot line at the core mantle boundary that in turn connects to the complex supersplume beneath the southern Atlantic and southern Africa. Along the far west boundary of the image, a sheet of cold (blue) materials representing subducted oceanic lithopshere beneath South America connects to the Chile trench at surface. A similar disintegrated sheet can be seen to plunge deep beneath north Africa; this probably represents the subducted African oceanic lithopshere in a slab-pull mode towards Africa, and is probably in part responsible for the low regional topography of central, west and north Africa. Thus the image begins to highlight that possible deep mantle processes are reflected in the surface topography of the lithosphere. Similar sheets beneath Asia have been linked to similar fossil subduction zones (Van der Voo et al., 1993). The reader is left to explore this figure further. Care should be taken not to over-interpret what is in effect a first-generation model. With increased computing power and improved global seismic and geological data, these images will no doubt converge towards more realistic models. For this current model there is no reference yet (courtesy of Hans-Peter Bunge and his research group, Munich, January 2007; for more details see Bunge et al., 1998; 2001). 
$\mathrm{CO}_{2}$ consumption during basalt weathering $\left(0.05 \times 10^{6}\right.$ $\mathrm{mol} / \mathrm{km}^{2} / \mathrm{yr}$ ) implies a total consumption of atmospheric $\mathrm{CO}_{2}$ of $150 \times 10^{16} \mathrm{~mol}$ (over 10 million years for a $3 \times 10^{6}$ $\mathrm{km}^{2}$ area). This is more than double the highest estimates of Cretaceous $\mathrm{CO}_{2}$ levels. From the mismatch between the volume of crust derived from the Kalahari highlands and the lesser amount of sediments accumulated around the margin than expected (Tinker, 2005; Tinker et al., 2007 in review), it can be safely assumed that some 30 to $50 \%$ of the basalt was returned to the oceans in solution. The buffering role in seawater uptake of $\mathrm{CO}_{2}$ during that process is also an important factor to consider on longer term climate changes (c.f. Edmond, 1992).

The mid Cretaceous ( $\sim 4$ to $\sim 90 \mathrm{Ma}$ ) was a time of high atmospheric $\mathrm{CO}_{2}$ concentration, and extreme global temperatures on an Earth without ice caps and average polar ocean temperatures of $\sim 20^{\circ} \mathrm{C}$ (Jenkyns et al., 2004). The period shortly thereafter (by the end of the Turonian, $89 \mathrm{Ma}$ ) heralds the onset of a long-term global cooling trend that reached its first minimum by the end Cretaceous, and from then continues into the Cenozoic. It remains to be resolved if the carbon budget changes related to the Kalahari epeirogeny balanced or changed the end Cretaceous greenhouse world to such a degree that it became a forcing factor in stimulating the onset of atmospheric $\mathrm{CO}_{2}$ decline and global cooling at the end of the Cretaceous (e.g. Jenkyns et al., 2004), long before the more dramatic cooling during the subsequent opening of the Drake Passage at $\sim 50 \mathrm{Ma}$ (Scher and Martin, 2006; Livermore et al., 2007).

A better understanding of the long term evolution of greenhouse gasses like $\mathrm{CO}_{2}$ within a framework of moving continents and transient ocean passages is important to estimate its influence on global climate (Fluteau et al., 1999; Fluteau, 2003) and perhaps even in sustaining further uplift of southern Africa (c.f. Molnar and England, 1990). Tracking the intricate details of the Kalahari epeirogeny is clearly pivotal in resolving these earth system links.

\section{Concluding remarks}

There is no solid consensus about the origin of the deep mantle low-velocity region below southern Africa and the effect it has on the surface topography above it. On the one hand, global seismic tomography has suggested a possible link with long term (Phanerozoiclength; 500 Ma) geologically determined subduction processes along the long-lived circum-Pacific/Tethyan master subduction zone around Pangea/Gondwana. This implies that whole mantle or lower mantle convection is primarily driven by cooling from above (top down cooling, e.g. Davis, 1993; Anderson 2000; Courtillot et al., 2003), via subduction of cold, dense lithosphere that settles at the core-mantle boundary (CMB) where it slowly heats up. Others believe that the low-velocity region is more directly related to differential heat loss from the core (bottom heating; Davaille 1999; Bunge et al., 2002 and references therein). These are fundamentally different geodynamic models of the solid Earth that are unresolved.

One robust observation that does seem to emerge from 3-D numerical modeling, which is helping to sharpen our understanding of the geodynamics of the solid Earth system, is that once a low-velocity mantle heterogeneity forms at the $\mathrm{CMB}$, it remains in place and becomes difficult to 'erase'. Indeed it seems to control mantle dynamics for a significant time span beyond its first emergence (e.g. compare Figures 4 and 9). Assuming a simple relationship between heat loss from the core and magnetic field variations (as a proxy for core dynamics), this can be tested. A high resolution of the magnetic record should in principle be able to decide the cause and effect relationships (c.f. Courtillot et al., 2007); careful analyses of the stratigraphic record should in principle be able to trace back the evolution of deep mantle upwelling (c.f. White and Lovell, 1999) that numerical 3-D modeling is now able to simulate to a tantalizing degree (Bunge et al., 2002; Conrad and Gurnis 2003).

From our first order analyses of the Kalahari epeirogeny, it appears that top-down driven pressure release in the upper mantle, and bottom-up heating from the lower mantle both contribute to liberation fronts of fluids via the mantle transition zone that in turn continues to be replenished through subduction. Tracking this cycle in more detail should provide a better understanding of the interactions between the solid earth and its fluid-envelope. Glimpses provided through analyzing the Kalahari epeirogeny reveal a complex $\mathrm{CO}_{2}$ cycle against which to benchmark palaeoclimate change models. The stratigraphic record preserved on and around southern Africa is a better place than elsewhere from which to decipher the links between these systems via the Kalahari epeirogeny. Feedback processes between the core, mantle, lithosphere, and the fluid-envelope, which in tandem affect climate and magnetic field changes, are implicated in sustaining the Kalahari epeirogeny and further shaping its future. Yet we are only beginning to understand its history. Inkaba yeAfrica offers a unique opportunity of collaboration to improve on this. To resolve the cause and effect of the Kalahari epeiorogeny in greater detail will require more robust bridging between palaeo mantle-dynamics and present day mantle-lithosphere tomography; better coupling with Gondwana break-up models; a more precise exhumation history of the Kalahari region and the high fidelity stratigraphy preserved on and along its margins; and then iteratively testing against 3-D geodynamic numerical models. Inkaba yeAfrica has progressed a significant way towards this, but there is still a long road ahead.

\section{Acknowledgements}

I would like to thank Arthur Fuller, Moctar Doucouré, Mike de Wit, Hielke Jelsma, Dave Apter, John Ward, Roger Hart, Sam Bowring, Danny McPhee, David Bell, 
Kevin Burke, Jacek Stankiewicz, Alex Kounov, Justine Tinker, Rod Brown, Stephanie de Villiers, Giulio Viola, Judith Masters, John Decker and Woody Cotterill to make me think about Africa and its topography from very different perspectives. I benefited from discussions at GFZ with Ofra Klein-BenDavid and Peter Wirth about fluid inclusions in diamonds, and at UCT with Stephanie de Villiers about basalt erosion. Thanks to Peter Bunge, Christoph Moder and Bernard Schuberth (University of Munich) for discussions about their dynamic mantle modeling and for help to create Figure 9; to Achim Helm at GFZ for discussions about the geoid and for creating Figure 3; and to Martin Homann and John Decker in helping to produce Figures 1 and 5, respectively. I am deeply grateful to Rolf Emmermann for the many opportunities to engage with German colleagues and to encourage the initiation and sustained development of Inkaba yeAfrica thinking; to Jörg Erzinger and Brian Horsfield for their hospitality, help and discussions whilst at GFZ, to Gabbi Uenzelmann-Neben for facilitating discourse at AWI in Bremerhaven, and to Vincent Courtillot for orchestrating many extensive discussions with him and colleagues at IPGP in France. I have benefited from lively interactions at all five Inkaba yeAfrica workshops between 2001 and 2006, and I thank all the participants at these meetings for their generosity in sharing their data and ideas. The work over this period was supported financially through GFZ, DST (through NRF), and de Beers Africa Exploration. I thank $S$ de Villiers, G Viola, D Bell, $\mathrm{H}$ Jelsma and $\mathrm{B}$ Horsfield for careful reviews. This is AEON contribution no. 33, and Inkaba yeAfrica contribution number 08 .

\section{References}

Alonso and ten co-authors (2006). Tectonics, climate, and landscape evolution of the southern central Andes: the Argentina Puna Plateau and regions between 22 and $30^{\circ} \mathrm{S}$. In: O.Oncken et al. (Editors). The Andes. Springer Verlag. Berlin Heidelberg. 265-283.

Anderson, D.L. (1979). Chemical stratification of the mantle. Journal of Geophysical Research, 84, 6279-6298.

Anderson, D.L. (2000). The thermal state of the upper mantle: no role for mantle plumes. Geophysical Research Letters, 27, 3623-3626.

Bayon, G., Vigier, N., Burton, K.W., Brenot, A., Carigan, J., Etoubleau, J. and Nan-Chin, C. (2006). The control of weathering processes on riverine and seawater hafnium isotope ratios. Geology, 34, 433-436.

Basson I.J. and Viola G. (2004). Passive kimberlite intrusion into actively dilating dyke-fracture arrays: evidence from fibrous calcite veins and extensional cleavage. Lithos, 76, 283-297.

Beaumont, C., Fullsack, P., and Hamilton, J. (2001). Himalayan tectonics explained by extrusion of low viscocity crustal channel coupled to focused surface denudation. Nature, 414, 738-742.

Becker, M. and Le Roex, A.P. (2006). Geochemistry of South African On- and Off- craton, Group I and Group II kimberlites: Petrogenesis and source region evolution. Journal of Petrology, 47, 673-703.

Beloussow, V.V. (1962). Basic problems in geotectonics. McGraw-Hill, New York, United States of America, 809pp.

Bell, D.R.,Schmitz, M.D. and Janney, P.E. (2003). Mesozoic thermal evolution of Precambrian lithosphere. Lithos, 71, 273-287.

Bell, D.R., Gregoire, M., Grove, T.L., Chatterjee, N., Carlson, R.W. and Buseck, P.R. (2003). Si- and volatile element metasomatism of Archean mantle. A xenolith scale example from the Kaapvaal Craton. Contributions to Mineralogy and Petrology, 150, 251-267.

Bell, D.R. and Moore, R.O. (2004). Deep chemical structure of the southern
African mantle from kimberlite megacrysts. South African Journal of Geology, 107, 59-80.

Benoit, M.H., Nyblade, A.A., Owens, T.J. and Stuart, G. (2006). Mantle transition zone structure and upper mantle $S$ velocity variations beneath Ethiopia: evidence for a broad, deep seated thermal anomaly. Geochemistry, Geophysics, Geosystems, 7, Q11013, doi.10.1029/2006GC001398.

Berg, G.W. (1986). Evidence for carbonate in the mantle. Nature, 349, 321-324.

Bierman, P.R. and Caffee, M. (2001). Slow rates of rock surface erosion and sediment production across the Namib desert and escarpment, southern Africa. American Journal of Science, 301, 326-358.

Bierman, P.R. and Nichols, K.K. (2004). Rock to sediment - slope to sea with ${ }^{10} \mathrm{Be}$ - rates of landscape change. Annual Reviews Earth and Planetary Sciences, 32, 215-255

Blum, J. and Shen, Y. (2004). Thermal, hydrous, and mechanical states of the mantle transition zone beneath southern Africa. Earth and Planetary Letters, 217, 367-378.

Bond, G.C. (1979). Evidence for some uplifts of large magnitude in continental platforms. Tectonophysics, 61, 285-306.

Boyd, F.R. and Gurney, J.J. (1986). Diamonds in the African lithopshere. Science, 232, 472-477.

Boyd, F., Gurney, J. and Richardson, S. (1985). Evidence for a 150-200 km thick Archean lithosphere from diamond inclusion thermobarometry. Nature, 315, 387-388.

Brown, L.F. Jr., Benson, J.M., Brink, G.J., Doherty, S., Jollands, A., Jungslager, E.H.A., Keenan, J.H.G., Muntingh, A. and van Wyk, N.J.S. (1995). Sequence Stratigraphy in Offshore South African Divergent Basins: An Atlas on Exploration for Cretaceous Lowstand Traps by Soekor (Pty) Limited. American Association Petroleum Geology, Studies in Geology. 41. 184pp.

Brown, R.W., Gallagher, K., Gleadow, A.J.W. and Summerfield, M.A. (2000). Morphotectonic evolution of the South Atlantic margins of Africa and South America. In: M. A Summerfield (Editor), Geomorphology and Global Tectonics. John Wiley and Sons Limited, United Kingdom, 255-284.

Brown, R.W., Summerfield, M.A. and Gleadow, A.J.W. (2002). Denudation history along a transect across the Drakensberg Escarpment of southern Africa derived from apatite fission track thermochronology. Journal of Geophysical Research, 107, B12, 2350. doi:10.1029/2001JB000745.

Bunge, H-P., Richards, M.A., Lithgow-Bertelloni, C., Baumgardner, J.R., Grand, S.P. and Romaowicz, B.A. (1998). Time scales and heterogeneous structure in geodynamic Earth models. Science, 280, 91-95.

Bunge, H-P., Richards, M.A. and Baumgardner, J.R. (2002). Mantle-circulation models with sequential data assimilations: inferring present-day mantle structure from plate-motion history. Philosophical Transactions of the Royal Society, London. A 360, 2545-2567.

Burke, K. C. (1996). The African Plate. South African Journal of Geology, 99, 341-409.

Burke, K.C. (1976). The Chad Basin: an active inter-continental basin. Tectonophysics, 36, 197-206.

Burke, K.C. and Wilson, J.T. (1972). Is the African Plate stationary? Nature, 239, 387-390.

Carlson, R.W., Czamanske, G., Fedorenko, V. and I. Ilupin (2006). A comparison of Siberian meimechites and kimberlites: implications for the source of high-Mg alkalic magmas and flood basalts. Geochemistry, Geophysics, Geosystems, 7, Q11014, doi.10.1029/2006GC001342.

Carminati, E., Wortel, M.J.R., Spakman, W. and Sabadini, R. (1998). The role of slab detachment processes in the opening of the western-central Mediterranean basins: some geological and geophysical evidence. Earth and Planetetary Science Letters, 160, 651-665.

Chevallier, L. and Woodford, A. (1999). Morpho-tectonics and mechanism of emplacement of the dolerite rings and sills of the western Karoo, South African Journal of Geology, 102, 43-54.

Chevrot, S. and Zhao, L. (2007). Multiscale finite-frequency Raleight wave tomography of the Kaapvaal craton. Geophyics Journal International, doi:10.1111/j.1365-246X.2006.03289.x, 1-15p.

Censier, C. (1996). Alluvial diamond deposits in the Central African Republic. African Geoscience Reviews, Special Issue, 61-74.

Clifford, T.N. (1966). Tectono-metallogenic units and metallogenic provinces of Africa. Earth and Planetary Science Letters, 1, 421-434.

Cockburn, H.A.P., Brown, R.W., Summerfield, M.A. and Seidl, M.A. (2000). Quantifying passive margin denudation and landscape development using 
a combined fission-track thermochronometry and cosmogenic isotope analysis approach. Earth and Planetary Science Letters, 179, 429-435.

Collins, W.J. (2003). Slab pull, mantle convection, and Pangeaean assembly and dispersal. Earth and Planetary Science Letters. 205, 225-237.

Conrad, C.P. and Gurnis, M. (2003). Sesimic tomography, surface uplift, and the breakup of Gondwanaland: integrating mantle convection backwards in time. Geochemistry, Geophysics, Geosystems, 4, 1031, doi: 1029/2001GC000299.

Courtillot, V, Gallet, Y., Le Mouëll, J-L., Fluteau, F. and Genevey, A. (2007) Are there connections between the Earth's magnetic field and climate? Earth and Planetary Science Letters, 253, 328-339.

Courtillot, V. Davaille, A., Besse, J. and Stock, J. (2003). Three distinct types of hotspots in the Earth's mantle. Earth and Planetary Science Letters, 205, 295-308.

Courtillot, V, Ducruix, J. and le Mouëll, J-L. (1978). Sur une accélération récente de la variation séculaiere du champ magnétique terrestre. Compte Rendue Geosciences, D287, 1095-1098.

Courtillot, V., Jaupart, C., Manighetti, T., Tapponnier, P and Besse, J. (1999) On casual links between flood basalts and continental break up. Earth and Planetary Science Letters, 166. 177-195.

Conrad, C. and Gurnis, M. (2003). Seismic tomogrpahy, surface uplift, and the break up of Gondwanaland: integrating amntle convection backwards in time. Geochemistry, Geophysics, Geosystems, 4, 1031, doi: 10.1029/2001GC000299.

Cox, K.G. (1978). Flood basalts, subduction and the break-up of Gondwanaland. Nature, 274, 47-49.

Cox, K.G. (1989). The role of mantle plumes in the development of continental drainage patterns. Nature, 342, 873-877.

Crough, S.T. (1979). Hotspot epeirogeny. Tectonophysics, 61, 321-334.

Dale, D.C. and McMillan, I.K. (1999). On the Beach: A Field Guide to the Late Cainozoic Micropalaeontological History, Saldanha Region, South Africa. De Beers Marine Publication, Cape Town. 127p.

Dalton, J.A. and Wood, B. (1993). The composition of primary carbonate melts and their evolution through wallrock reactions in the mantle. Earth and Planetary Science Letters, 119, 511-525.

Dassinnies, M.C.D., Jacobs, J., Kohn, B. and Grantham, G.H. (2004) A Combined Apatite Fission Track And Apatite (U-Th)/He Study Of The Passive Continental Margin Of Northern Mozambique. 10th International Fission Track Dating and Thermochronology. 8-13th August, 2004, Amsterdam (abstract), 72.

Davaile, A. (1999). Simultaneous generation of hotspots and superswells by convection in a heterogeneous planetary mantle. Nature, 402, 756-760.

Davis, G.F. (1993). Cooling the core and mantle by plume and plate flows. Geophysicsal Journal International, 115, 132-146.

Dessert, C., Dupre, B., Francois, L.M., Schott, J., Gaillardait, G.L. Chakrapani and Bajai, S. (2001). Erosion of the Deccan Trapps determined by river geochemistry: impact on the global climate and the ${ }^{87} \mathrm{Sr} /{ }^{86} \mathrm{Sr}$ ratio of seawater. Earth and Planetary Science. Letters. 188, 459-474.

Dewey, J.F., Helman, M.L., Turco, E., Hutton, D.H.W. and Knott, S.D. (1989). Kinematics of the western Mediterranean. In: M.P. Coward, D. Dietrich and R. G.Park (Editors), Alpine Tectonics, The Geological Society, London, Special Publication, 45, 265-283.

Dewey, J.F., Pitman, W.C., Ryan, W.B.F. and Bonnin, J. (1972). Plate Tectonics and the Evolution of the Alpine System. Geological Society of America Bulletin, 84, 3171-3180.

de Wit, M.C.J. (1993). Cainozoic evolution of the drainage systems in the north-western Cape. Unpublished PhD thesis, Univeristy of Cape Town, South Africa, 371pp.

de Wit, M.J.C., Marshall, T.R. and Partridge, T.C. (2000). Fluvial deposits and drainage evolution. In: T.C. Partridge and R.R. Maud (Editors), The Cenozoic of southern Africa. Oxford University Press, United Kingdom. 55-72.

de Wit, M.J., Stankiewicz, J. and Reeves, C. (2007). Restoring Pan-African Brasíliano connections: more Gondwana control, less Trans-Atlantic corruption. In: R. J. Pankhurst, R. A. J. Trouw, B. B. Brito Neves and M. J. de Wit, M.J. (Editors) West Gondwana: pre-Cenozoic correlations across the South Atlantic region, The Geological Society, London, Special Publications (in press).

de Wit, MJ and Horsfield, B. (2006). Inkaba yeAfrica Project surveys sector of Earth from core to space. EOS, Transactions, American Geophysical Union, 87, 11, 113, 117. de Wit, M.J. and Tinker, J. (2004). A composite deep-seismic reflection section across the central Kaapvaal craton. South African Journal of Geology, 107, 185-206.

de Wit, M.J., Jeffery, M., Bergh, H., Nicolaysen, L. O. (1988). Geological Map of Sectors of Gondwana Reconstructed to their Dispositions at $\sim 150 \mathrm{Ma}$, Scale 1:10,000,000. American Association of Petroleum Geology.

de Wit, M.J., Roering, C., Armstrong, R.A., Tredoux, M., de Ronde, C.E.J., Hart, R.J., Green, R., Peberdy, E. and Hart, R.A. (1992). Formation of an Archaean continent. Nature, 357, 553-562.

Dingle, R.V., Siesser, W.G. and Newton, A.R. (1983). Mesozoic and Tertiary Geology of southern Africa. A.A. Balkema, Rotterdam. The Netherlands, $375 \mathrm{pp}$.

Dormy, E. and Mandea, M. (2005). Tracking geomagnetic impulses at the core-mantle boundary. Earth and Planetary Science Letters, 237, 300-309.

Doucouré, C.A. and de Wit, M.J. (2003a). Old inherited origin for the present near bimodal topography of Africa. Journal of African Earth Sciences, 36, 371-388.

Doucouré, C.M. and de Wit, M.J. (2003b).Temporal variation in rigidity and mechanical behaviour of old thick continental lithosphere. South African Journal of Geology, 105, 39-50.

Doyle, P.M., Bell, D.R and le Roex, A.P. (2004). Fine-grained pyroxinites from the Gansfontein kimberlite, South Africa: evidence from megacryst magmamantle interaction. South African Journal of Geology, 107, 285-300.

Duncan, R.A., Hooper, P.R., Rehacek, J., Marsh, J.S. and Duncan, A.R (1997). The timing and duration of the Karoo igneous event, southern Gondwana. Journal of Geophysical Research 102, 18127-18138.

Dupré, B., Dessert, C., Oliva, P., Goddéris, Y., Viers, J., François, L., Millot, R and Gaillardet, J. (2003). Rivers, chemical weathering and Earth's climate. Compte Rendue Geosciences, 335, 1141-1160.

Durheim, R.J. and Mooney, W.D. (1994). Evolution of the Precambrian lithosphere: seismological and geochemical constraints. Journal of Geophysical Research, 99, 15359-15374.

Du Toit, A.L. (1933). Crustal movement as a factor in the geographical evolution of South Africa. The South African Geographical Journal, 16, 4-20.

Eagles, G. (2007). New angles on South Atlantic opening. Geophysical Journal International. 166, 353-361.

Eagles, G and König, M. (2007). Jurassic and early Cretaceous plate kinematics of central Gondwana. Geophysical Journal International (in press).

Ebinger C. J. and Sleep, N.H. (1998). Cenozoic magmatism throughout east Africa resulting from the impact of a single plume. Nature, 395, 788-791.

Edmond, J. (1992). Himalayan tectonics, weathering processes and the strontium isotope record in marine limestones. Science, 258, 1594-1597.

Elliot, D.H., Fleming, T.H. (2000). Weddell triple junction: the principal focus of Ferrar and Karoo magmatism during initial breakup of Gondwana. Geology 28, 539-542.

Erlank, A., Waters, F., Hawkesworth, C., Haggerty, S., Allsopp, H., Richard, R. and Menzies, M. (1987). Evidence for mantle metasomatism in peridotite nodules from the Kimberlite Pipes, South Africa. In: M. Menzies and C. J. Hawkesworth (Editors), Mantle metasomatism. Academic Press, London, United Kingdom, 221-311.

Faccenna, C., Piromallo, C., Crespo-Blanc, A. and Jolivet, L. (2004). Lateral slab deformation and the origin of the western Mediterranean arcs. Tectonics, 23, TC1012, doi: 10.1029/2002TC001488.

Fairhead, J.D. and Binks, R.M. (1991). Differential opening of the Central and South Atlantic Oceans and the opening of the Central African rift system. Tectonophysics, 187, 191-203.

Fluteau, F. (2003). Earth dynamics and climate change. Compte Rendue Geoscience. 335, 157-174.

Fluteau, F., Ramstein, G., and Besse, J. (1999). Simulating the evolution of the Asian and African monsoons during the past 30 Ma using an atmospheric general circulation model. Journal of Geophysical Research, 104, 11995-12018.

Freybourger, M., Gaherty, J. and Jordan, T. (2001). Structure of the Kaapvaal craton from surface waves. Geophysical Research Letters. 28, 2489-2492.

Fleming, A., Summerfield, M.A., Stone, J.O.H., Fifield, L.K. and Cresswell, R.G. (1999). Denudation rates for the southern Drakensberg escarpment, SE Africa, derived from in-situ-produced cosmogenic ${ }^{36} \mathrm{Cl}$ : initial results. Journal of the Geological Society, London, 156, 209-212.

Flowers, R.M., Royden, L.H. and Bowring, S.A. (2004). Isostatic constraints 
on the assembly, stabilization, and preservation of cratonic lithosphere. Geology 32, 321-324.

Foster, D.A. and Gleadow, A.J.W. (1996). Structural framework and denudation history of the flanks of the Kenya and Anza rifts. Tectonics, 15, 258-271.

Fouch, M.J., James, D.E., Van Decar, J.C., van der Lee, S. (2004). Mantle seismic structure beneath the Kaapvaal and Zimbabwe Cratons. South African Journal of Geology, 107, 33-44.

Fukao, Y., Maruyama, S., Obayashi, M. and Inoue, H. (1994). Geologic implications of whole mantle p-Wave tomography. Journal of the Geological Society of Japan, 100, 4-23.

Fuchs, K., von Gehlen, K., Malzer, H., Murawski, H. and Semmel., A. (1983) Epilogue: mode and mechanism of Rhenish Plateau uplift. In: K. Fuchs et al. (Editors), Plateau uplift. Springer-Verlag, Berlin Heidelberg, Germany, 405-410.

Fuller, A. (1972). Possible fracture zones and rifts in southern Africa. Geological Society of America, Memoir 132, 159-172.

Gallagher, K. and Brown, R. (1999). The Mesozoic denudation history of the Atlantic margins of southern Africa and southeast Brazil and the relationship to offshore sedimentation. In: N. R. Cameron, R. H. Bate and V. S. Clure (Editors), The Oil and Gas Habitats of the South Atlantic. Geological Society, London, Special Publications, 153, 41-53.

Gohl, K and Uenzelmann-Neben, G. (2001). The crustal role of the Agulhas Plateau, southwest Indian Ocean: evidence from seismic profiles. Geophysical Journal International., 144, 632-646.

Gregoire, M., Bell, D.R. and le Roex, A.P. (2003). Garnet lherzolites from the Kaapvaal craton (South Africa): trace element evidence for a metasomatic history. Journal of Petrology, 44, 629-657.

Grand, S.P. (2002). Mantle shear-wave tomography and the fate of subduction slabs. Philosophical Transactions of the Royal Society, Series A360, 2475-2491.

Grand, S.P., van der Hilst, R.D. and Widiyantore, S. (1997). Global seismic tomography: a snapshot of convection in the Earth. GSA Today, 7, 1-3.

Gu, Y., Dziewonski, A.M. and Agee, C.B. (1998). Global de-correlation of the topography of the transition zone discontinuities. Earth and Planetary Science Letters, 157, 57-68.

Gurney, J.J. and Harte, B. (1980). Chemical variations in the upper mantle nodules from southern African kimberlites. Philosphical Transactions of the Royal Society, London, A279, 273-293.

Guiraud, R., Binks, R.M., Faihead, J.D. and Wilson, M. (1992). Chronology and geodynamic setting of Cretaceous-Cenozoic rifting in West and Central Africa. Tectonophysics, 213, 227-234.

Gurnis, M. (1988). Large-scale mantle convection and the aggregation and dispersal of supercontinents. Nature, 332, 695-699.

Gurnis, M., Mitrovica, J.X., Ritsema, J. and van Heijst, H.-J. (2000). Constraining mantle density structure using geological evidence of surface uplift rates: the case of the African Superplume. Geochemistry, Geophysics, Geosystems, 1, doi: 10.1029/1999GC000035.

Hafkenscheid, E.,Wortel, M.J.R. and Spakman, W. (2006). Subduction history of the Tethyan region derived from seismic tomography and tectonic reconstructions. Journal of Geophysical Research, 111, B08401, doi: 10.1029/2005JB003791.

Hanson E.K., Moore J.M., Robey J.A., Bordy E.M. and Marsh J.S. (2006). Reestimation of erosion levels in Group I and II kimberlites between Lesotho, Kimberley and Victoria West, South Africa. 8th International Kimberlite Conference, Victoria, Canada, Extended abstract.

Harris, M., Le Roex, A.P. and Class, C. (2004). Geochemistry of the Uintjiesberg kimberlite, South Africa: petrogenesis of an off-craton, group I kimberlite. Lithos, 74, 149-165.

Hawkesworth, C.S., Kelley, S., Turner, S., Le Roex, A. and Storey, B. (1999). Mantle processes during Gondwan break-up and dispersal. Journal of African Earth Sciences, 28, 239-261.

Hawthorne, J.B. (1975). Model of a kimberlite pipe. Physics and Chemistry of the Earth, 9, 1-16.

Hinz, K., Neben, S. Scheckenberger, H.A., Roeser, H.A., Block, M., Goncalves de Souza, and Meyer, H. (1999). The Argentine continental margin north of 480S: sedimentary successions, volcanic activity during break-up. Marine and Petroleum Geology, 16, 1-25.

Holmes, A. (1965). Principles of Physical Geology. (2nd Edition). William Clowes and Sons Limited, Edinburgh, United Kingdom, 532pp.

Illies, J.H., Prodehl, C., Schminke,H.-U. and Semmel. (1979). The Quaternary uplift of the Rhenish Shield in Germany. Tectonophysics, 61, 197-225.

Irufine, T. and Ringwood, A.E. (1993). Phase transformations in subducted oceanic crust and buoyancy relationships at depths of $600-800 \mathrm{~km}$ in the mantle. Earth and Planetary Science Letters, 117, 101-110.

Isacks, B., Mueller, I., Walcott, R.I. and Talwani, M. (1973). Vertical crustal motions and their causes. EOS, American Geophysical Union, 54, 1257-1260.

Ishii, M. and Tromp, J. (1999). Normal-mode and free-air gravity constraints on lateral variations in velocity and density of Earth's mantle, Science, 285, 1231-1236.

Izraeli, E.S., Harris, J.W. and Navon, O. (2001). Brine inclusions in diamonds: a new upper mantle fluid. Earth and Planetary Science Letters, 187, 323-332.

James, D., Boyd, F.R., Schutt, D, Bell, D.R. and Carlson, R.W. (2004). Xenoliths constraints on sesimic velocities in the upper mantle beneath southern Africa, Geochemistry Geophysics, Geosystems, 5, Q01002, doi: 10.1029/2003GC000551.

James, D., Fouch, M., VanDecar, J. and van der Lee, S. 2001. Tectospheric structure beneath southern Africa. Geophysical Research Letters. 28, 2485-2488.

Jelsma, H., A., de Wit, M.J., Thiart, C., Skinner, E.M.W., Dirks P.H.G.M., Viola G., Basson I.J. and Anckar E. (2004). Preferential distribution along transcontinental corridors of kimberlites and related rocks of southern Africa. South African Journal of Geology, 107, 301-324.

Jenkyns, H.C., Forster, A., Schouten, S. and Sinninghe Damsté, J.S. (2004). High temperature in the late Cretaceous Arctic Ocean. Nature, 432, 888-892.

Jokat, W., Boebel, M., König, M. and Meyer, U. (2003). Timing and geometry of the early Gondwana break up. Journal of Geophysical Research, 108, 2428, doi: 10.1029/2002.JB001802.

Jordan, T. H. (1975). The continental tectopshere. Reviews of geophysics and Space Physics, 13, 1-12.

Jordan, T. H. (1988). Structure and formation of the continental tectosphere. Journal of Petrology, Special lithosphere Volume, 11-37.

Jourdan, F., G. Féraud, H. Bertrand and M. K. Watkeys (2007). From flood basalts to the inception of oceanization: Example from the ${ }^{40} \mathrm{Ar} /{ }^{39} \mathrm{Ar}$ highresolution picture of the Karoo large igneous province, Geochemistry, Geophysics, Geosystem., 8, Q02002, doi:10.1029/2006GC001392.

Kaban, M.K., Schwintzer, P., Artemieva, I.M. and Mooney, W.D. (2003). Density of the continental roots compositional and thermal contribution. Earth and Planetary Science Letters, 209, 53-59.

Klein-BenDavid, O., Izraeli, E.S., Hauri, E. and Navon, O. (2006a). Fluid inclusions in diamonds from the Diavik Mine, Canada, and the evolution of diamond-forming fluids. Geochemica et Cosmochemica Acta, doi:10.1016/j.gca.2006.10.008.

Klein-BenDavid, Wirth, R. and Navon, O. (2006b). TEM imaging and analysis of microinclusions of diamond: a close look at diamond growing fluids. American Mineralogist 91, 253-353.

King, L.C. (1951). South African Scenery, 2nd Edition. Oliver and Boyd, Edinburgh, United Kingdom, 379pp.

King, L.C. (1967). The Morphology of the Earth. Oliver and Boyd, Edinburgh, United Kingdom, 699pp.

König, M. (2006). Processing of shipborne magnetometry data and revision of timing and geometry of the Mesozoic break-up of Gondwana. Reports on Polar and Marine Research 525. Alfred Wegener Institute, Bremerhaven, Germany. 137pp.

Kounov, A., Niedermann S., Viola G., Andreoli M., Erzinger J. and de Wit, M.J. (2006). Mesozoic-Cenozoic denudation along the Atlantic passive margin and its hinterland, with implications for the origin of the great escarpment. Abstract 6th Inkaba yeAfrica Workshop, GFZ-Potsdam, Germany.

Kounov, A., Niedermann S., de Wit, M.J, Viola G., Andreoli M. and Erzinger J. (2007). Present day denudation rates bearing on erosion processes along selected west- and south-facing sections of the South African Great Escarpment and its interior derived from in situ produced cosmogenic ${ }^{3} \mathrm{He}$ and ${ }^{21}$ Ne. South African Journal of Geology, 110,

Lamb, S. and Davis, P. (2003). Cenozoic climate change as a possible cause for the rise of the Andes. Nature, 425, 792-797.

Larson, R.L. (1991). Latest pulse of the Earth: evidence for a mid-Cretaceous superplume. Geology, 19, 547-550.

Le Pichon, X. and Huchon, P. (1984). Geoid, Pangea and convection. Earth and Planetary Science Letters, 67, 1234-1235 
Le Roex, A.P. (1986). Geochemical correlation between southern African kimberlites and South Atlantic hotspots. Nature, 230, 85-87.

Le Roex, A.P., Bell., D.R. and Davis, P. (2003). Petrogenesis of Group kimberlites from Kimberley, South Africa: Evidence from bulk geochemistry. Journal of Petrology, 44, 2261-2286.

Le Stunff, Y., Wicks Jr., C.W. and Romanowicz, B.(1995). P'P'precursors under Africa: evidence for mid-mantle reflectors, Science, 270, 74-77.

Lithgow-Bertelloni C. and Silver P.G. (1998). Dynamic topography, plate driving forces, and the African superswell. Nature, 395. 296-273.

Livermore, R., Hillenbrand, C.D., Meridith, M. and Eagles, G. (2007). Drake Passage and Cenozoic climate: an open and shut case? Geochemistry, Geophysics, Geosystem, 8, Q01005, doi: 10.1029/2005GC001224.

Loper, D.E. and McCartney, K. (1986). Mantle plumes, and periodicity of magnetic field reversals or flood basalts. Geophysical Research Letters, 13, 1525-1528.

Maaløe, S. (2005). Extraction of melt from a veined mantle source region during eruption. Journal of Volcanology and Geothermal Research. 147, 377-390.

Marsh, J.S., Hooper, P.R., Rehacek, J., Duncan, R.A. and Duncan, A.R. (1997). Stratigraphy and age of Karoo Basalts of Lesotho and implications for correlations within the Karoo igneous province. In: J. J. Mahoney and M. F. Coffin, M.F. (Editors), Large Igneous Provinces. American Geophysical Union Monograph 100, 247-272.

McGetchin, T.R., Burke, K.C., Thompson, G.A. and Young, R.A. (1980). Mode and mechanisms of plateau uplift. In: A. W. Bailey, P. L. Bender, T. R McGetchin and R. I. Walcott. (Editors), Dynamics of Plate interiors. Geodynamics Series, Volume 1. American Geophysical Union and Geological Society of America, 99-100.

McGetchin, T.R. and Merrill, R.B. (Editors) (1979). Plateau uplift: mode and mechanisms. Tectonophysics, 61, 1-336.

McKenzie, D. (1984). A possible mechanism for epeirogenic uplift. Nature, 307, 616-618.

McMillan, I.K. (2003). Foraminiferally defined biostratigraphic episodes and sedimentation pattern of the Cretaceous drift succession (Early Barremian to Late Maastrichtian) in seven basins on the South African and southern Namibian continental margin. South African Journal of Science. 99, 537-576.

McMillan, I.K., Brink, G.J., Broad, D.S. and Maier, J.J. (1997). Late Mesozoic Sedimentary Basins Off the South Coast of South Africa. In: R. C. Selley (Editor), African Basins. Sedimentary Basins of the World, Elsevier Science B.V. Amsterdam. 3, 319-376.

Menard, H.W. (1973). Epeirogeny and plate tectonics. EOS, American Geophysical Union, 54, 1244-1255.

Merrer, S., Cara, M., Rivera, L. and Ritsema, J. (2007). Upper mantle structure beneath continents: New constraints from multi-mode Rayleigh wave data in western North America and southern Africa. Geophysical Research Letters. 34, L06309

Michaut, C., Jaupart, C. and Bell, D.R. (2007). Transient geotherms in Archean continental lithopshere: new contraints on thickness and heat production of the subcontinental lithopshere mantle. Journal of Geophysical Research 112, doi:10.1029/2006JB004464.

Mierdel, K., Keppler, H., Smyth, J.R. and Langenhorst, F. (2007). Water solubility in aluminous orthopyroxene and the origin of earth's astenopshere. Science, 315, 364-368

Molnar, P. and England, P. (1990). Late Cenozoic uplift of mountain ranges and global climate change: chicken or egg. Nature, 346, 29-34.

Molnar, P., England, P. and Martinod, J. (1993). Mantle dynamics, uplift of the Tibetan Plateau and the Indian monsoon. Reviews of Geophysics, 31, 357-396

Montelli, R., Nolet, G., Dahlen, F.A. and Masters, G. (2006). A cataloque of deep mantle plumes: new results from finite-frequency tomography. Geochemistry, Geophysics, Geosystems, 7, Q11007, doi: 10/1029/2006GC001248.

Montelli, R., Nolet, G., Dahlen, F.A. and Masters, G. Engdahl, E.R. and Hung, S.-H. (2004). Finite-frequency tomography reveals a variety of plumes in the mantle. Science, 303, 338-343.

Moore, A. (1999). A reappraisal of epeirogenic flexure axis in southern Africa. South African Journal of Geology, 102, 363-376.

Moore, A. and Blenkensop, T. (2006). Scarp retreat versus pinned drainage divide in the formation of the Drakenberg escarpment, southern Africa. South African Journal of Geology, 109, 599-610.
Moser, D.E., Flowers, R.M. and Hart, R.J. (2001). Birth of the Kaapvaal tectosphere 3.08 billion years ago. Science, 291, 465-468.

Nair, S.K., Gao, S.S., Liu, K.H. and Silver, P.G. (2006). Southern African crustal evolution and composition: constrains from receiver function studies. Journal of Geophysical Research, 111, BO2304, doi:10.1029/2005JB003802. Neugebauer, H.J., Woidt, W. D. and Waller, H. (1983). Uplift, Volcanism and Tectonics: Evidence for mantle diapirs at the Rhenish Massif. In: K. Fuchs et al. (Editors). Plateau uplift. Springer Verlag, Berlin-Heidelberg, Germany. 381-403.

Nguuri, T., Gore, J., James, D.E., Webb, S., Wright,C., Zengeni, T.G., Gwavava, O. and Snoke, J.A. (2002). Crustal structure beneath southern Africa and its implications for the formation and evolution of the Kaapvaal and Zimbabwe Cratons. Geophysical Research Letters, 28, 2501-2504.

Niu, F., Levander, A., Cooper, C.M., van der Lee, C.A., Lenardic, A. and James, D.E. (2004). Seismic constraints on the depth and composition of the mantle keel beneath the Kaapvaal craton. Earth and Planetary Science Letters, 224, 337-346.

Nicolaysen, L.O. (1985a). On the physical basis for the extended Wilson cycle, in which most continents coalesce and then disperse again. South African Journal of Geology, $\mathbf{8 8}, 562-580$.

Nicolaysen, L.O. (1985b). Renewed ferment in the Earth Sciences - especially about power supplies for the core, for the mantle and for crises in the faunal record. South African Journal of Science, 81, 120-132.

Nishiyama, N., Rapp, R.P., Irifune, T., Sanehira, T., Yamazaki, D. and Funakoshi, K. (2005). Stability and P-V-T equation of state of KALSI3O8Hollandite determined by insitue X-Ray observations and implications for dynamics of subducted continental crust material. Physics and Chemistry of Minerals 32, 627-637.

Nyblade, A.A. and Robinson, S.W. (1994). The African superswell. Geophysical Research Letters, 21, 765-768.

Nyblade, A.A. and Langston, C.A. (2002). Broadband seismic experiments probe the east African Rift. EOS, Transactions American Geophysical Union, 83, 405-408.

Nyblade, A.A., Knox, R.P. and Gurrola, H. (2000a). Mantle transition zone thickness beneath Afar: implications for the origin of the Afar hotspot. Geophysical Journal International, 142, 615-619.

Nyblade, A.A., Owens, T.J., Gurrola, H., Ritsema, J. and Langston, C.A. (2000b). Seismic evidence for a deep upper mantle thermal anomaly beneath east Africa. Geology, 28, 599-602.

Nyblade, A. A. and Sleep, N.H. (2003). Long lasting epeirogenic uplift from mantle plumes and the origin of the Southern African Plateau. Geochemistry, Geophysics, Geosystems, 4, (2003GC000573).

Oncken, O, Hindle, D., Kley, J., Elger, K., Victor, R. and Schemmann, K. (2006). Deformation of the central Andean upper plate system - facts, fiction and contraints for plate models. In: O.Oncken et al. (Editors). The Andes. Springer Verlag. Berlin, Germany. 3-27.

O'Reilly, S.Y. and Griffith, W.L. (2006). Imaging chemical and thermal heterogeneities in the subcontinental lithopshere mantle with garnets and xenoliths: geophysical implications. Tectonophysics, 416, 289-309.

O'Reilly, S.Y. and Griffith, W.L. (1996). 4-D lihtosphere mapping methodology and examples. Tectonophysics 262, 3-18.

Partridge, T.C. (1998). Of diamonds, dinosaurs and diastrophism: 150 million years of landscape evolution in southern Africa. South African Journal of Geology, 101, 165-184.

Partridge, T.C. and Maud, R.R. (1987). Geomorphic evolution of southern Africa since the Mesozoic. South African Journal of Geology, 90, 179-208. Partridge, T.C. and Maud, R.R. (2000). Macro-scale geomorphic evolution of southern Africa. In: T. C. Partridge and R. R. Maud (Editors), The Cenozoic of Southern Africa. Oxford University Press, United Kingdom, 3-18.

Parman, S.W., Grove, T.L., Dann, J.C. and de Wit, M.J. (2004). A subduction origin for komatiites and cratonic lithopshere. South African Journal of Geology, 107, 107-118.

Paton, D.A., Van der Spuy, D., de Primo, R and Horsfield. B. (2007). Tectonically induced adjustment of passive margin accomodation space; influence on hydrocarbom potential of the Orange basin, South Africa. American Association of Petroleum Geologists, (in press)

Phipps Morgan, J., Reston, T.J. and Ranero, C.R. (2004). Contemporaneous mass extinctions, continental flood basalts, and 'impact'signals: are mantle plume induced lithospheric gas explosions the causal link? Earth and Planetary Science Letters, 217, 263-284.

Priestley, K., (1999). Velocity structure of the continental mantle: evidence 
from southern Africa. Lithos, $\mathbf{4 8}, 45-56$

Priestley, K., McKenzie, D. and Debayle, E. (2006). The state of the mantle beneath southern Africa. Tectonophysics, 416, 101-112.

Raab, M.J., Brown, R.W., Gallagher, K., Weber, K. and Gleadow, A.J.W (2004). The post break-up denudation chronology of Namibia's passive Margin. 10th International Fission Track Dating and Thermochronology 8-13th August, 2004, Amsterdam (abstract). 80.

Raab, M.J., Brown, R.W., Gallagher, K., Carter, A. and Weber, K. (2002). Late Cretaceous reactivation of major crustal shear zones in northern Namibia: constraints from apatite fission track analysis. Tectonophysics. 349, 75-92.

Ramberg, H. (1967). Gravity, deformation and the Earth's crust. Academic Press, New York, United States of America, 214pp.

Ramstein, G., Fluteau, F., Besse, J. and Joussaume, S. (1997). The effect of orogeny, plate motion and land-sea distribution on Euraisan climate change over the past 30 million years. Nature, 386, 788-795.

Raymo, M.E. and Ruddiman, W.F. (1992). Tectonic forcing of late Cenozoic climate. Nature 359, 117-122.

Reeves, C. and de Wit, M.J. (2000). Making ends meet in Gondwana retracing the transforms of the Indian Ocean and reconnecting continental shear zones. Terra Nova, 12, 272-280.

Reilinger R. (and 24 coauthors). (2006). GPS constraints on continental deformation in the Africa-Arabia-Eurasia continental collosion zone and implications for the dynamics of plate interactions. Journal of Geophysical Research, 111, B05411, doi:10.1029/2005JB004051.

Ringwood, A.E. (1967). The pyroxene-garnet transformation in the Earth's mantle. Earth and Planetary Science Letters, 2, 255-263.

Ringwood, A.E. (1982). Phase transformatins and differentiation in subducted lithosphere: implications for mantle dynamics, basalt petrology and crustal evolutin. Journal of Geology, 90, 611-643.

Ringwood, A.E. (1991). Phase transformations and their bearing on the constitution and dynamics of the mantle. Geochimica et Comochimica Acta, 55, 2083-2110.

Ritsema, J and Van Heijst, H. (2000). New seismic model of the upper mantle beneath Africa. Geology, 28, 63-66.

Ritsema, J., Van Heijst, H.J. and Woodhouse, J.H. (1999). Complex shear wave velocity structure immaged beneath Africa and Iceland. Science, 286, 925-1928

Ritsema, J., Van Heijst, H.J. and Woodhouse, J.H. (2004). Global transition zone tomography. Journal of Geophysical Research 109, doi:10.1029/2003JB002610.

Rosenbaum, G., Lister, G.S. and Duroz C. (2002). Relative motions of Africa, Iberia and Europe during the alpine orogeny. Tectonophysics, 359, 117-129.

Sahagian, D.L. (1988). Epeirogenic motions of Africa as inferred from Cretaceous shore line deposits. Tectonics, 7, 125-138.

Sautter,V., Haggerty, S.E. and Field, S. (1993). Ultradeep (>300 kilometer) ultramafic xenoliths: petrological evidence for the transition zone. Science, 252, 827-830.

Scher, H.D. and Martin, E.E. (2006). Timing and climatic consequences of the opening of the Drake Passage. Science, 312, 428-430.

Schmitz, M and Bowring, S. (2003). Constraints on the thermal evolution of the continental lithopshere from $\mathrm{U} / \mathrm{Pb}$ accessory mineral thermochronometry of lower crustal xenoliths. Contribution to Mineralogy and Petrology, 144, 592-618.

Schmitz, M.D. and Bowring, S.A. (2004). Lower crustal granulite formation during Mesoproterozoic Namaqua-Natal collisional orogenesis, southern Africa. South African Journal of Geology, 107, 261-284.

Schmitz, M.D., Bowring, SA, de Wit, MJ and Graz, V. (2004). Subduction and terrane collision stabilized the western Kaapvaal craton tectosphere 2.9 billion years ago: Earth and Planetary Science Letters, 222, 363-37.

Schoene, B. and Bowring, S.A. (2006). Determining accurate temperature-time paths from $\mathrm{U}-\mathrm{Pb}$ thermochronology: An example from the Kaapvaal craton, southern Africa, Geochimica et Cosmochimica Acta, 71.

Schulze, D. J. (1989). Constraints on the abundance of eclogite in the upper mantle. Journal of Geophysical Research 94, 4205-4212.

Scotese, C. R. (2001). Atlas of Earth History. (2001). Palaeomap Progress report, 90-0497, Department of Geology, University of Texas, Arlington, Texas, United States of America.

Shen, Y and Blum, J. (2003). Seismic evidence for accumulated oceanic crust above the 660-km discontinuity beneath southern Africa. Geophysical
Research Letters, 30, 1925, doi:10.1029/2003GL017991

Shirey, S.B., Harris, J.W., Richardson, S.H., Fouch, M.J., James, D.E., Cartigny, P., Deines, P and Viljoen, F. (2005). Diamond genesis, seismic structure, and the evolution of the Kaapvaal-Zimbabwe craton. Science, 297, 1683-1686.

Skinner, E.M.W., Clement, C.R., Gurney, J.J. Apter, D.B. and Hatton, C.J. (1992). The distribution and tectonic controls of South African kimberlites. Russian Geology and Geophysics, 33, 26-31.

Smith, A.G. (1971). Alpine deformation and the oceanic areas of the Tethys, Mediterranean and Atlantic. Geological Society of America Bulletin, 82, 2039-2070.

Smith, A.G. (1982). Late Cenozoic uplift of stable continents in a reference frame fixed to South America. Nature, 296, 400-404.

Smith, A.G. (2006). Tethyan ophiolite emplacement, Africa to Europe motion and Atlantic spreading. In: A. E. F. Robertson and D. Mountain (Editors), Tectonic development of the eastern Mediterranean Region. The Geological Society, London, Special Publication, 260, 11-34.

Smith, M. (1994). Stratigraphic and structural constraints on mechanisms of active rifting in the Gregory Rift, Kenya. Tectonophysics, 236, 3-22.

Sobelov, A.V. and 19 coauthors. (2007). The amount of recycled crust in sources of mantle-derived melts. Science, 316, 412-417.

Stampfli, G.M. and Borel, G.D. (2004). The TRANSMED transects in space and time: constraints on the paleotectonic evolution of the Mediterranean domain. In: $\mathrm{W}$ Cavazza et al. (Editors), The TRANSMED atlas: the Mediterranean region from crust to mantle. Springer Verlag, Berlin, Heidelberg, p53-80

Stankiewicz, J. and de Wit, MJ. (2006). A proposed drainage evolution model for Central Africa - Did the Congo flow east? Journal of African Earth Sciences, $\mathbf{4 4}, 75-84$.

Stankiewicz, J., Chevrot, S., van der Hilst, R.D. and de Wit, M.J. (2002). Crustal thickness, discontinuity depth and upper mantle structure beneath southern Africa: constraints from body wave conversions. Physics of Earth and Planetary Interiors, 130, 235-251.

Stern, C.R. and de Wit, M.J. (2004). Rocas Verdes ophiolite, southernmost South America: remnants of progressive stages of development of oceanic type crust in a continental back arc basin. In: de Y. Dilek and P.T. Robinson (Editors), Ophiolites in Earth History. The Geological Society, London, Special Publication, 218, 665-683.

Stille, H. (1948). Die assynthische Tectonik im geologischen Errhbild. Beilage Geologische Jahrbuch, Heft 22, 255pp.

Storey, B.C. (1995). The role of mantle plume in continental break-up: case histories from Gondwana. Nature, 377, 301-306.

Storey, B.C., Curtis, M.L., Ferris, J.K., Hunter, M.A. and Livermore, R.A. (1999). Reconstruction and break-out for the Falkland Islands within Gondwana. Journal of African Earth Sciences, 29, 153-163.

Storey, B.C. and Kyle, P.R. (1997). An active mantle mechanism for Gondwana breakup. South African Journal of Geology, 100, 283-290.

Storey, B.C., Leat, P.T. and Ferris, J.K. (2001). The location of mantle plume centres during the initial stages of Gondwana break up. Geological Society of America Special Paper, 352, 71-80.

Summerfield, M.A. (1996). Tectonics, geology and long-term landscape development. In: W. M. Adams, A. S. Gondie and A. R. Orme (Editors), The Physical Geography of Africa. Oxford University Press, United Kingdom, 1-17.

Svensen, H., Jamtveit, B., Planke, S and Chevallier, L (2006). Structure and evolution of hydrothermal vent complexes in the Karoo Basin, South Africa. Journal of the Geological Society, London, 163, 671-682; doi: 10.1144/1144-764905-037.

Tankard, A.J., Jackson, M.P., Eriksson, K.A. Hobday, D.K. Hunter, D.R. and Minter, W.E.L. (1982). Crustal Evolution of Southern Africa: 3.8 Billion Years of Earth History, Springer-Verlag, New York, United States of America, 523pp.

Tappert, R., Stachel, T., Harris, J.W., Muehlenbachs, K., Ludwig, T. and Brey, G.P. (2005a). Subducting oceanic crust: the source of deep diamonds. Geology, 33, 565-568.

Tappert, R., Stachel, T., Harris, J.W., Muehlenbachs, K., Ludwig, T. and Brey, G.P. (2005b). Diamonds from Jaggersfontein (South Africa): meesegers from the sublithopsheric mantle. Contribributions to Mineralogy and Petrology, 150, 505-522.

Thompson, G.A. and Zoback, M.L. (1979). Regional geophysics of the Colorado Plateau. Tectonophysics, 61, 149-181. 
Tinker, J. (2005). Using apatite fission track thermochronology and offshore sedimentary volumes to test the balance between denudation (onshore) and deposition (offshore) since Gondwana break-up. Unpublished PhD Thesis. University of Cape Town, South Africa, 243pp.

Tinker, J, de Wit, M.J. and Brown, R. (2007). Mesozoic uplift of southern Africa: using fission track thermochronology and offshore sediment volumes to test the balance between onshore denudation and offshore accumulation since Gondwana break-up. Tectonophysics (under revision) Trumbull, R B., Reid, D.L., de Beer, C., van Acken, D. and Romer, R.L. (2007) Magmatism and continental breakup at the West Margin of Southern Africa: A geochemical comparison of dolerite dikes from northwest Namibia and the Western Cape. South African Journal of Geology, 110, 477-502.

Twidale, C.R., (1994). Gondwana (late Jurassic and Cretaceous) palaeosurfaces of the Australian Craton. Palaeogeography, Palaeoclimatology, Palaeoecology 112, 157-186.

Uenzelmann-Neben, G and Gohl, K. (2004). The Agulhas ridge, South Atlantic: the peculiar structure of a fracture zone. Marine Geophysical Research, 25, 305-319.

Uenzelmann-Neben, G, Gohl, K., and Ehrhardt, A. (1999). Agulhas Plateau, SW Indian Ocean: new evidence for excessive volcanism. Geophysical Research Letters, 26, 1941-1944.

Umbgrove, J.H.F. (1947). The Pulse of the Earth. (Second Edition). Martinus Nijhoff, The Hague. The Netherlands, 358pp.

Vaughan, A.P.M. and Scarrow, J.H. (2000). Ophiolite obduction pulses as a new proxy for superplume events. Abstracts with programs, Geological Society of America, 32, 379-380.

Van Bemmelen, R.W. (1966). On mega undulations: a new theory for Earth's evolution. Tectonophysics, 3, 83-127.

Van der Hilst, R. and Kárason, H. (1999). Compositional heterogeneity in the bottom $1000 \mathrm{~km}$ of the earth's mantle: towards a hybrid convection model. Science, 283, 1885-1888.

Van der Voo, R., Spakman, W. and Bijwaard, H. (1999). Mesozoic subducted slabs under Siberia. Nature, 246-249.

Vearncombe, S. and Vearncombe, J.R. (2002). Tectonic controls on kimberlite location, southern Africa. Journal of Structural Geology, 24, 1619-1625.

Veizer, J., Ala, D., Azmy, K., Bruckschen, P., Buhl, D., Bruhn, F., Carden,
G.A.F., Diener, A., Ebneth, S., Goderis, Y., Jasper, T., Korte, C., Powellek, F., Podlaha, O.G. and Strauss, H. (1999). 87Sr $/ 86 \mathrm{Sr}$, d13C and d18O evolution of Phanerozoic seawater. Chemical Geology, 161, 59-88.

Vinnik, L.P., Green, R.W.E., Nicolaysen, L.O., Kosarev, G.L. and Petersen, N.V. (1996). Deep seismic structure of the Kaapvaal craton. Tectonophysics, 262, 67-75.

Walker, J.C.G., Hays, P.B. and Kasting, J.F. (1981). A negative feedback mechanism for long-term stabilization of earth's surface temperature. Journal of Geophysical Research, 86, 9776-9782.

White, N. and Lovell, B. (1997). Measuring the pulse of a plume in the sedimentary record. Nature, 387, 888-891.

Wilson, L. and Head, J.W. (2007). An integrated model of kimberlite ascent and eruption. Nature, 447, 53-57.

Wirth, R., Vollmer, C., Brenker, F., Matsyuk, S. And Kaminsky, F. (2007). Inclusions of nanocrystaline hydrous aluminum silicate „Phase Egg“ in superdeep diamonds from Juina (Mato Grosso Stae, Brazil). Earth and Planetary Science Letters, 259, 384-399.

Wittlinger, G. and Farra, V. (2007). Converted waves reveal a thick and layered tectosphere beneath the Kalahari super-craton. Earth and Planetetary Science Letters, 254, 404-415.

Wortel, M.J.R. and Spakman, W. (2000). Subduction and slab detachment in the Mediterranean-Carpathian region. Science, 290, 1910-1917.

Wyllie, P. (1979). Magmas and volatile components. American Mineralogist, 64, 469-500.

Wyllie, P.(1987). Discussion of recent papers on carbonated peridotite, bearing on mantle metasomatism and magmatism. Earth and Planetary Science Letters, 82, 391-397.

Yirgu, G., Ebinger, C. J. and Maguire, P.K.H. (2006). The Afar volcanic province within the East African Rift System. The Geological Society, London, Special Publication, 259, 327pp.

Zhao, D. (2004). Global tomographic immages of mantle plumes and subducting slabs: insight into deep Earth dynamics. Earth and Planetary Science Letters, 192, 251-265.

Editorial handling: Brian Horsfield 